\title{
The vertical variability of black carbon observed in the atmospheric boundary layer during DACCIWA
}

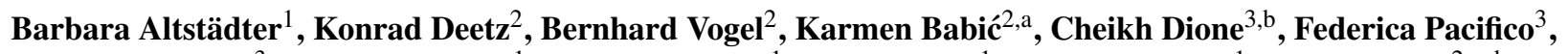 \\ Corinne Jambert ${ }^{3}$, Friederike Ebus ${ }^{1}$, Konrad Bärfuss ${ }^{1}$, Falk Pätzold ${ }^{1}$, Astrid Lampert ${ }^{1}$, Bianca Adler ${ }^{2, c, d}$, \\ Norbert Kalthoff ${ }^{2}$, and Fabienne Lohou ${ }^{3}$ \\ ${ }^{1}$ Institute of Flight Guidance, Technische Universität Braunschweig, Braunschweig, Germany \\ ${ }^{2}$ Institute of Meteorology and Climate Research, Karlsruhe Institute of Technology, Karlsruhe, Germany \\ ${ }^{3}$ Laboratoire d'Aérologie, Université de Toulouse, CNRS, UPS, Toulouse, France \\ ${ }^{a}$ now at: Croatia Control Ltd., Velika Gorica, Croatia \\ bnow at: African Centre of Meteorological Applications for Development, Niamey, Niger \\ ${ }^{\mathrm{c}}$ now at: CIRES, University of Colorado, Boulder, CO, USA \\ ${ }^{d}$ now at: NOAA Physical Sciences Laboratory, Boulder, CO, USA
}

Correspondence: Barbara Altstädter (b.altstaedter@tu-braunschweig.de)

Received: 10 June 2019 - Discussion started: 11 July 2019

Revised: 26 May 2020 - Accepted: 15 June 2020 - Published: 8 July 2020

\begin{abstract}
This study underlines the important role of the transported black carbon (BC) mass concentration in the West African monsoon (WAM) area. BC was measured with a micro-aethalometer integrated in the payload bay of the unmanned research aircraft ALADINA (Application of Lightweight Aircraft for Detecting IN situ Aerosol). As part of the DACCIWA (Dynamics-Aerosol-Chemistry-Cloud Interactions in West Africa) project, 53 measurement flights were carried out at Savè, Benin, on 2-16 July 2016. A high variability of BC (1.79 to $2.42 \pm 0.31 \mu \mathrm{g} \mathrm{m}^{-3}$ ) was calculated along 155 vertical profiles that were performed below cloud base in the atmospheric boundary layer (ABL). In contrast to initial expectations of primary emissions, the vertical distribution of $\mathrm{BC}$ was mainly influenced by the stratification of the ABL during the WAM season. The article focuses on an event (14 and 15 July 2016) which showed distinct layers of $\mathrm{BC}$ in the lowermost $900 \mathrm{~m}$ above ground level (a.g.l.). Low concentrations of $\mathrm{NO}_{x}$ and $\mathrm{CO}$ were sampled at the Savè supersite near the aircraft measurements and suggested a marginal impact of local sources during the case study. The lack of primary $\mathrm{BC}$ emissions was verified by a comparison of the measured $\mathrm{BC}$ with the model COSMO-ART (Consortium for Small-scale Modelling-Aerosols and Reactive Trace gases) that was applied for the field campaign period. The modelled vertical profiles of BC led to the assump-
\end{abstract}

tion that the measured BC was already altered, as the size was mainly dominated by the accumulation mode. Further, calculated vertical transects of wind speed and $\mathrm{BC}$ presume that the observed $\mathrm{BC}$ layer was transported from the south with maritime inflow but was mixed vertically after the onset of a nocturnal low-level jet at the measurement site. This report contributes to the scope of DACCIWA by linking airborne $\mathrm{BC}$ data with ground observations and a model, and it illustrates the importance of a more profound understanding of the interaction between $\mathrm{BC}$ and the $\mathrm{ABL}$ in the WAM region.

\section{Introduction}

Black carbon (BC) is one of the major contributors affecting the Earth's climate system. Freshly emitted BC caused by incomplete combustion is insoluble in water and strongly absorbs solar radiation in the visible spectrum (Bond et al., 2013). Once BC is emitted into the atmosphere, ongoing physical and chemical reactions, like secondary aerosol formation, influence the composition and mixing state of aerosol particles. Aged BC can act as cloud condensation nuclei after hygroscopic growth in the atmosphere (Zhang et al., 2008), which ultimately contributes to the indirect aerosol ef- 
fect. The understanding of the BC life cycle is still poor, as the monitoring of the type and source of combusted products, ageing processes in the atmosphere, and the current knowledge of wet deposition differ in terms of the measurement methods used, and simulations show high discrepancy (e.g. Li et al., 2017).

The role of $\mathrm{BC}$ emissions is of special interest in regions with a dense population. For instance, the population in southern West Africa is proposed to grow to more than 800 million by the middle of the century (Knippertz et al., 2015a); consequently, a degradation of air quality and human health is expected due to ongoing anthropogenic pollution. Liousse et al. (2014) compared three different future scenarios for African emissions in the year 2030 if no regulations for combustion are implemented. The calculated BC emission factors varied between 2 and 4 in comparison with 2005, meaning possible emissions of more than $2.5 \mathrm{Tg} \mathrm{BC}^{-1}$, which would be comparable with $20 \%-30 \%$ of the BC emissions worldwide.

Investigating the impact of growing air pollution on the southern West Africa area at a regional and global scale is one subject of the DACCIWA (Dynamics-AerosolChemistry-Cloud Interactions in West Africa) project (see Knippertz et al., 2015b). DACCIWA aims at understanding complex interactions between aerosols, clouds, and their impact on climate and weather in south-western Africa. The study combines in situ and aircraft observations that are further compared with satellite data and models. The intensive field experiment of DACCIWA was carried out in June-July 2016 during the West African monsoon (WAM) (e.g. Knippertz et al., 2017; Flamant et al., 2018; Kalthoff et al., 2018). The aerosol composition in the WAM region is mainly influenced by the large-scale synoptic pattern (Mari et al., 2008). During July and September, biomass burning smoke from southern Africa is the dominant contributor during the WAM season and is proposed as a major source for $\mathrm{BC}$, as retrieved by satellite data and simulations (Huang et al., 2009). Horizontal transects were performed with aircraft at a coastal site in south-western Africa, and the results for the $\mathrm{PM}_{1}$ concentration are shown in Brito et al. (2018). Interestingly, the observed $\mathrm{BC}$ fraction of the aerosol composition varied only minimally $(6 \%)$ above in-plume flights in comparison with background concentrations of $\mathrm{BC}$, with $0.34 \mu \mathrm{g} \mathrm{m}^{-3}$ in the lowermost $2 \mathrm{~km}$. The observations are in agreement with simulations by Huang et al. (2009), showing that the BC concentration is more likely dominated by long-range transport triggered by the WAM instead of local biomass burning emissions.

However, previous data showed only the large-scale variability of BC instead of columns on smaller scales of a few square kilometres above one particular measurement field. The relationship between the atmospheric boundary layer (ABL) and $\mathrm{BC}$ distributions in particular needs more profound investigations. Liu et al. (2018) studied the ABL height for $347 \mathrm{~d}$ depending on the classification of polluted (BC $\left.>5 \mu \mathrm{g} \mathrm{m}^{-3}\right)$ and non-polluted events $\left(\mathrm{BC}<5 \mu \mathrm{g} \mathrm{m}^{-3}\right)$ in Wuhan, China. The ABL height was suppressed on polluted days, which ultimately leads to poorer air quality. The reduction of the ABL height can be explained by the increase in absorption due to enhanced particulate matter originating from pollution (e.g. Petäjä et al., 2016). The growing absorption heats up the upper part of the ABL, which further results in an increase in stability. As a consequence of weaker turbulence and mixing in more stable conditions, the ABL height decreases. But in most investigations, BC is solely measured at the ground. Further, Liu et al. (2018) calculated the top of the ABL from lidar measurements neglecting cases with low clouds. So studies are missing with non-clear-sky days like during monsoon seasons.

Therefore, a large benefit can be expected by using unmanned aerial systems (UASs) for investigating the smallscale variability of $\mathrm{BC}$ in the $\mathrm{ABL}$. Relating to $\mathrm{BC}$ measurements, optical methods based on the light-absorbing principle are common. The development of miniaturised BC instrumentation is essential, as reduced size and limitations of weight are the main challenges of new sensor integration on airborne platforms. Wilcox et al. (2016) presented vertical profiles of $\mathrm{BC}$, measured with a miniaturised threewavelength absorption photometer (Corrigan et al., 2008) on a UAS, during the winter monsoon over the northern Indian Ocean. BC loads were higher in the lowermost $3 \mathrm{~km}$ on polluted days in comparison with days of minor pollution observed at the surface. A lower ABL height was estimated during polluted days, supporting the current understanding of feedback mechanisms, as was summarised in Petäjä et al. (2016). However, the observations showed an increase in humidity in the surface mixed layer that might favour cloud formation, which is in contrast to the understanding of a lower instability and minor turbulence due to the absorption of aerosols in the ABL. Thus, further studies are essential to better understand the role of $\mathrm{BC}$ in the $\mathrm{ABL}$ and to consider other potential impacts on the vertical distribution in a broader range.

The objective of the current study is to investigate the small-scale vertical variability of $B C$ and its relation with the ABL by using the UAS ALADINA (Application of Lightweight Aircraft for Detecting IN situ Aerosol) at a remote site in West Africa. To the authors' knowledge, there has been no study of the vertical distribution of BC obtained by unmanned research aircraft in the WAM region so far. Subsequently, the $\mathrm{BC}$ distribution within the $\mathrm{ABL}$ is presented in general for the whole observation period (2-16 July 2016), in particular for an event (14-15 July 2016). In order to quantify the small-scale vertical BC distribution and to assess the role of small-scale local emissions, the airborne data were compared with ground monitoring and the COSMO-ART (Consortium for Small-scale Modelling-Aerosols and Reactive Trace gases) model of the DACCIWA framework. More precisely, observations for the wind profiler, ceilometer, and gas concentrations are taken into account that were installed 
$4 \mathrm{~km}$ away from the research flights in order to characterise the current weather situation and possible sources for BC. The COSMO-ART model is used as an indicator of particle size and distribution.

The article is structured as follows: the UAS ALADINA and its instrumentations are introduced in Sect. 2. The model set-up of COSMO-ART is provided in Sect. 2.4, and the measurement sites are presented in Sect. 2.5. The results are discussed in Sect. 3, and the outcome of the study is summarised in Sect. 4.

\section{Instrumentation, model, and measurement site}

\subsection{The unmanned aerial system ALADINA}

There is a wide range of airborne platforms, including UASs operating with batteries and fuel engines, as well as fixed wings and multicopters, that are applied for atmospheric research at various sampling locations (e.g. Mayer et al., 2010; Marino et al., 2015; Renard et al., 2016; Jiménez et al., 2016; Cuxart et al., 2016; Båserud et al., 2016; Brosy et al., 2017). The different systems have advantages and shortcomings. In terms of ALADINA, the aircraft is electrically powered so that any contamination of the measured air probe can be prevented. Thus, a qualitative analysis of aerosol particles is guaranteed by sampling in short periods of time, as was done in previous studies using ALADINA (Platis et al., 2016; Altstädter et al., 2018) in Melpitz, Germany.

ALADINA was designed at the Technische Universität Braunschweig for atmospheric research, and it was steadily improved regarding current technical requirements. The Carolo P360 has a maximum take-off weight of $25 \mathrm{~kg}$ and a wing span of $3.6 \mathrm{~m}$. The modular payload bay offers the capacity for a payload weight of approximately $4 \mathrm{~kg}$. The pusher aircraft has an electrical propulsion and enables a flight duration of $40-50 \mathrm{~min}$ at a cruising speed of $28-30 \mathrm{~m} \mathrm{~s}^{-1}$ in the current configuration. ALADINA is operated manually during take-off and landing, whereas it is controlled automatically during measurement flights via autopilot. The flight time, accurate position, altitude, and attitude of the aircraft are given by the installed GPS (global positioning system) and IMU (inertial measurement unit). A precision of $\pm 1.5 \mathrm{~m}$ in constant height is provided by the autopilot system. The flight track follows predefined waypoints that are sent before take-off or during flight to the on-board computer and can be changed according to the specific scientific goals during measurement flights. Observed data and the flight path can be monitored via live transfer at a temporal resolution of $1 \mathrm{~Hz}$.

More information on the airplane itself can be found in Altstädter et al. (2015). The instrumentation was updated for DACCIWA and the set-up is provided in Bärfuss et al. (2018). All UAS data derived during DACCIWA are available from Bärfuss et al. (2017). Other aerosol sensors (optical particle counter and condensation particle counter) that are usually on ALADINA did not work properly during DACCIWA. One reason for this might be damage to the optical parts after transportation. But adjusting and calibration were not possible at the research site due to the lack of a laboratory, so the true causes could not be identified. Thus, the current study focuses explicitly on meteorology, and BC and the instrumentations are explained in the following sections.

\subsection{Meteorological sensors for turbulence measurements}

The meteorological sensor package is displayed in Fig. 1a. It consists of a multi-hole probe (number 1), temperature sensors (number 2-4), and humidity sensors (number 4 and 5). The meteorological sensors are mounted at the tip of the aircraft nose in order to ensure an undisturbed airflow.

The three-dimensional wind vector $(\boldsymbol{V})$ is derived via a multi-hole probe manufactured by the Institute of Fluid Dynamics (Technische Universität Braunschweig, Germany; e.g. Wildmann et al., 2014). The multi-hole probe is combined with an IMU-GPS system. The wind vector has a usable data rate of up to $100 \mathrm{~Hz}$ with an accuracy in wind speed components of $\pm 0.5 \mathrm{~m} \mathrm{~s}^{-1}$ and in wind direction of $\pm 10^{\circ}$. The methods for wind calculation are described in Bärfuss et al. (2018).

The air temperature is calculated from three temperature sensors based on different measurement techniques. A finewire element was manufactured at the Institute of Flight Guidance (Technische Universität Braunschweig, Germany) with a high temporal resolution of $30 \mathrm{~Hz}$ and an accuracy better than $\pm 0.05 \mathrm{~K}$ (see Fig. 1a, number 2). The sensor principle is comparable with a system described in Wildmann et al. (2013), but it was additionally protected with a housing against direct solar radiation, dust particles, and mosquitoes. In addition, a factory-calibrated capacitive sensor of type TSYS01 (Measurement Specialties, USA) was used with a resolution of around $0.3 \mathrm{~Hz}$ and a given accuracy of $\pm 0.1 \mathrm{~K}$ (see Fig. 1a, number 3). These two sensors were fused together into a long-term stable reading with an error of less than $\pm 0.1 \mathrm{~K}$ and used for this study. Further, air temperature was measured by an HMP110 (Vaisala, Finland) with a lower resolution of $0.5 \mathrm{~Hz}$ and $\pm 0.2 \mathrm{~K}$ accuracy (Fig. 1a, number 4).

The relative humidity is measured with a Rapid P14 element (Innovative Sensor Technology, Switzerland) and an HMP110 (Vaisala, Finland), both based on the capacitive measuring principle (Fig. 1a, number 4 and 5). The measurement range is from 0 to $95 \% \mathrm{RH}$ with an accuracy of $\pm 1.5 \% \mathrm{RH}$ in a temperature range between 0 and $40^{\circ} \mathrm{C}$, as specified by the manufacturer. The response time of $10 \mathrm{~s}$ resulted after combining the humidity sensors. 

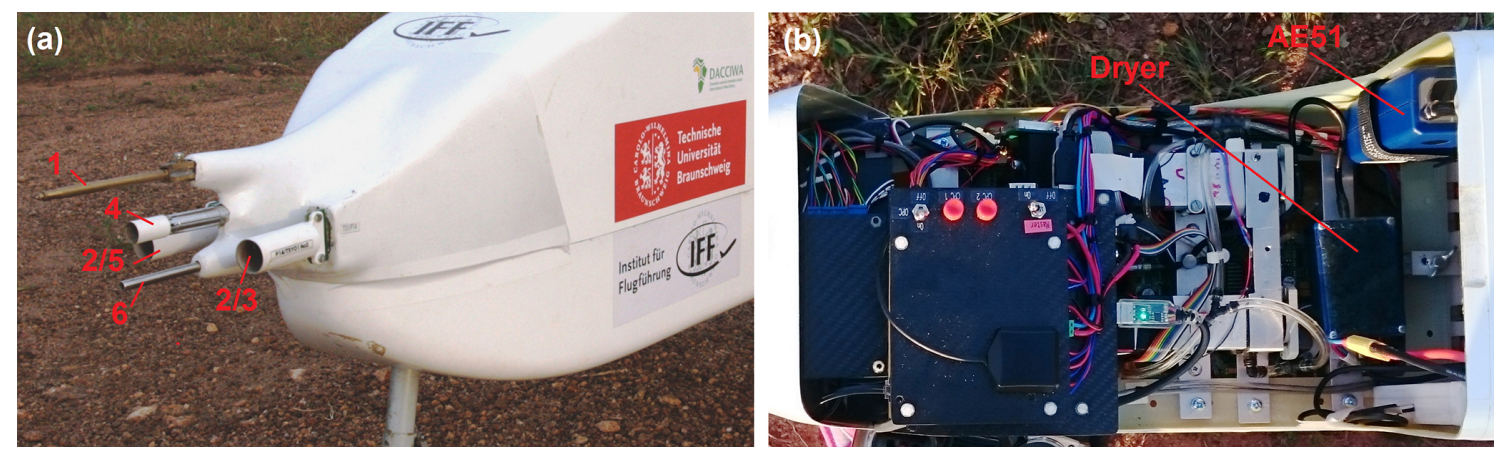

Figure 1. The pictures show the measurement units of the UAS ALADINA during DACCIWA in Savè. (a) The nose of ALADINA is equipped with meteorological sensors for calculating the three-dimensional wind vector with one multi-hole probe (number 1), temperature (number 2-4), and humidity (number 4 and 5). The air probe is sampled with one aerosol inlet (number 6) mounted at the tip of the aircraft's nose. (b) The micro-aethalometer AE51 is installed in the front compartment of the aircraft for adjusting the centre of gravity. The airstream is dried with silica gel before measuring (see the blue box close to the AE51). Photo: Institute of Flight Guidance, TU Braunschweig.

\subsection{Aethalometer for detecting BC mass concentration}

The one-wavelength micro-aethalometer (microAeth $^{\circledR}$ model AE51, AethLabs, USA) is a lightweight (around $280 \mathrm{~g}$ ) and easy-to-handle device for BC monitoring. It was implemented into the payload bay of ALADINA (see Fig. 1b). The aerosol inlet is installed at the front of the aircraft close to the meteorological sensors (Fig. 1a, number 6). The airstream was run at a flow rate of $150 \mathrm{~mL} \mathrm{~min}^{-1}$, and it was dried with silica gel before reaching the AE51 inlet in order to avoid strong influences of moisture on the filter stripe of the sensor.

Here, it has to be considered that different measurement methods (for instance, optical or chemical) lead to different types of BC. A clear terminology is mandatory, as recommended by Petzold et al. (2013). In terms of the presented study, the equivalent black carbon (EBC) was calculated from the AE51. For the sake of simplicity, the term BC instead of EBC will be used hereafter.

The $\mathrm{BC}$ mass concentration is estimated from the attenuation coefficient $\left(\sigma_{\mathrm{ATN}}\right)$ at the wavelength of $880 \mathrm{~nm}$ on an aerosol-loaded filter. In the case of the AE51, a T60 Tefloncoated borosilicate glass-fibre filter stripe is used that has to be manually changed after every measurement period. The measurement principle is based on the Lambert-Beer law, and the attenuation (ATN) is defined as follows:

$\mathrm{ATN}=-100 \cdot \ln \left(\frac{I}{I_{0}}\right)$

where the attenuation is calculated from the ratio of the light intensity $(I)$ transmitted through the loaded filter with respect to the initial intensity of the transmitted light $\left(I_{0}\right)$ on an aerosol-free filter stripe. Taken from Hansen et al. (1984), the attenuation is proportional to the surface concentration of BC. By taking into account the fact that the change in the attenuation $(\triangle \mathrm{ATN})$ is caused by an increase in the $\mathrm{BC}$ mass load on the filter stripe in a corresponding time interval $(\Delta t)$, the $\mathrm{BC}$ mass concentration can be derived as follows (Saturno et al., 2017):

$\mathrm{BC}=\frac{\sigma_{\mathrm{ATN}}}{\alpha_{\mathrm{ATN}}}=\frac{A \cdot \Delta \mathrm{ATN}}{\alpha_{\mathrm{ATN}} \cdot Q \cdot \Delta t}$.

$A$ is the filter stripe area, $\alpha_{\mathrm{ATN}}$ is the $\mathrm{BC}$ mass attenuation cross section at a wavelength of $880 \mathrm{~nm}$, and $Q$ is the volumetric flow rate. $\sigma_{\mathrm{ATN}}$ was corrected for artefacts which originate from the filter-based measurement technique (e.g. Weingartner et al., 2003; Virkkula et al., 2007; Collaud Coen et al., 2010; Ran et al., 2016).

The measurement range is $0-1 \mathrm{mg} \mathrm{BC} \mathrm{m}^{-3}$ with a resolution of $1 \mathrm{ng} \mathrm{BC} \mathrm{m}^{-3}$, as specified by the manufacturer. According to tests of the micro-aethalometer in the field and in the laboratory after the flight campaign, the accuracy was determined to $\pm 0.2 \mu \mathrm{g} \mathrm{BC} \mathrm{m}^{-3}$ at a response time of $1 \mathrm{~Hz}$.

The effects of meteorological conditions (sensitivity to temperature and humidity) on the instrument's readings and artefacts were characterised on different types of airborne platforms (e.g. Ferrero et al., 2014; Ran et al., 2016; Chiliński et al., 2018). However, a direct comparison of the AE51 on a UAS relating to ground observations has been missing so far. Pikridas et al. (2019) showed that the AE51 is a feasible tool for BC measurements on a UAS in an area of high background aerosol particle concentration. Flight campaigns were conducted in Athens and Cyprus. The results are based on a comparison of three different miniaturised absorption instruments (e.g. AE51) on a UAS with ground-based monitoring by the MAAP (Multi-Angle Absorption Photometer) and one micro-aethalometer of type AE33. According to the results of the Athens campaign, the correlation of AE5 1 was $R^{2}=0.76$ by sampling close to the ground for the relationship between MAAP and AE33. BC was underestimated by the AE51 by $6 \%$ to $7 \%$, thus within the given accuracy of $10 \%$. However, the comparison during the Cyprus campaign showed a high overestimation of $22 \%-55 \%$ BC by the AE51, possibly caused by the low background aerosol particle concentration 
at the research site. The low performance of the instrument for a small background concentration in generally clean air masses is one major issue of the AE51 (e.g. Ferrero et al., 2014; Lee, 2019). The impact should be of minor relevance for the current study, which addresses an area with high PM concentrations that partially exceed WHO guidelines (Adon et al., 2019). However, during laboratory tests it became apparent that the readings of the micro-aethalometer are also sensitive to changes in temperature and humidity. This will be further addressed.

\subsubsection{Influence of temperature changes and data post-processing}

As an example, the impact of temperature changes on the attenuation is shown for a flight that was performed with ALADINA on 14 July 2016 (flight ID 41 of 53 total measurement flights). Figure 2 presents the internal temperature from the micro-aethalometer (PCBtemp) during the measurement period from 05:16 until 06:30 UTC that varied between 27 and $36^{\circ} \mathrm{C}$. This flight was chosen as the worst-case scenario during the study. In order to determine the temporal evolution of temperature, the bit noise has to be filtered out by a smoothing algorithm. Taken from laboratory tests in a temperature chamber, the influence factor of temperature changes on $\mathrm{BC}$ measurements was determined to be of the order of $0.25 \mu \mathrm{g} \mathrm{BC}(\mathrm{d} T / \mathrm{d} t)^{-1}$. Applied for the current case, the largest temperature gradients were observed between 05:16 and 05:30 UTC during the first steps of the ascent, leading to a bias (shown as BC error in Fig. 2b) of $3 \mu \mathrm{g} \mathrm{BC} \mathrm{m}{ }^{-3}$. BC data were corrected with the internal temperature changes measured directly at the $\mathrm{BC}$ sensor for the whole study. Here, it should be clarified that these first steps of ascent, similar to all other flights, do not directly affect the analysis presented here. These first steps correspond to takeoff, which is handled by remote control by the responsible pilot. However, automatic flight tracks were exclusively used in order to obtain comparable vertical profiles, thus neglecting horizontal patterns. One possible cause of these large temperature gradients might be internal heating of the aircraft. During landing and preparation for the next research flight, the aircraft was directly exposed to sunlight. Another effect that could lead to this high BC error might be the load of the optical part. The error was reproducible in the laboratory, but the exact source of the error could not be determined. More tests in field studies would be mandatory.

During post-processing, the readings of the $\mathrm{BC}$ attenuation were phase-shift-free low-pass-filtered at different timescales of 10, 30, and $60 \mathrm{~s}$. Therefore, a high-pass Butterworth filter of third order was used, running forward and backward in order to eliminate phase shifts. Averaging was not applied for the attenuation signal to avoid poor frequency responses. Figure 3 shows the high variability of the attenuation signal for $1 \mathrm{~s}$ temporal resolution during a measurement flight between 15:58 and 16:42 UTC on 10 July 2016. The results with the (a)
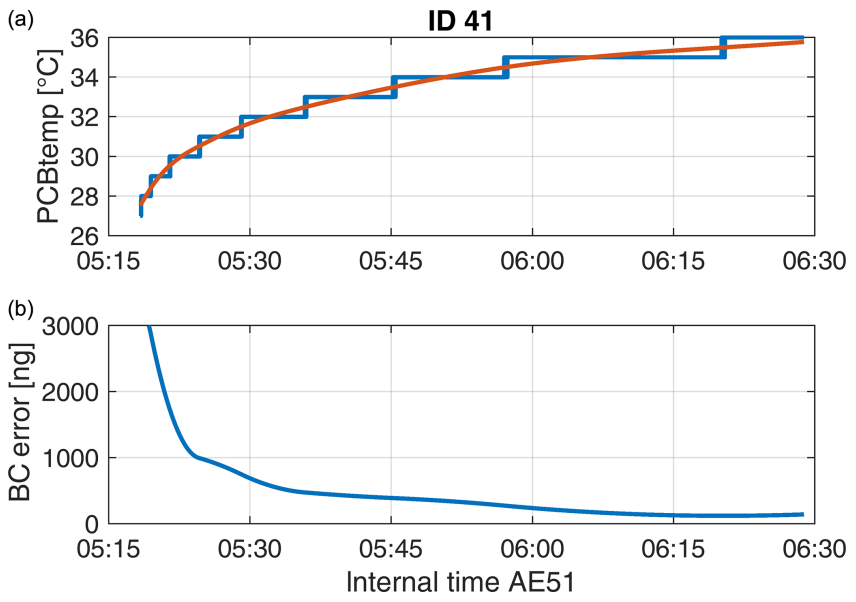

Figure 2. The figure shows the internal temperature (PCBtemp) of the aethalometer AE51 during the measurement flight from 05:16 until 06:30 UTC on 14 July 2016 (a). The bit noise was smoothed for the time interval (red line). Panel (b) represents the calculated error of the black carbon mass concentration.

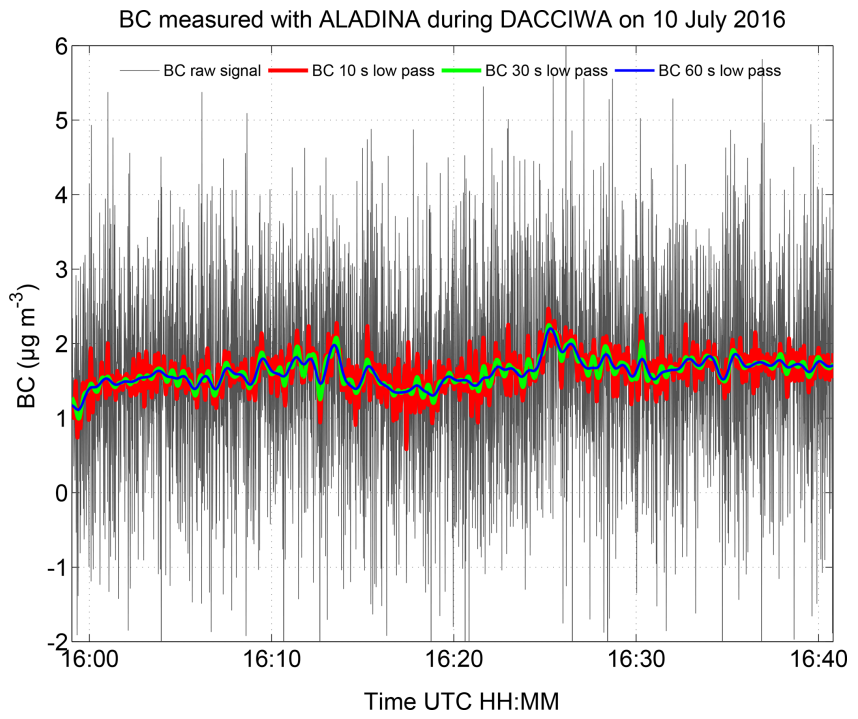

Figure 3. BC mass concentration measured during one flight between 15:58 and 16:42 UTC on 10 July 2016. The raw signal of BC (grey line) was phase-shift-free low-pass-filtered after postprocessing with $10 \mathrm{~s}$ (red line), $30 \mathrm{~s}$ (green line), and $60 \mathrm{~s}$ (blue line).

highest possible temporal resolution but still acceptable noise (standard deviation smaller than $0.3 \mu \mathrm{g} \mathrm{m}^{-3}$ or $22 \%$ of the signal) were obtained by a low-pass filter with a span of $10 \mathrm{~s}$. The mean attenuation was $1.59 \pm 0.30 \mu \mathrm{g} \mathrm{m}^{-3}$, varying between 0.5 and $2.5 \mu \mathrm{g} \mathrm{m}^{-3}$. As the frequency response will be lost by a span of $30 \mathrm{~s}$ or more, the method with a $10 \mathrm{~s}$ lowpass filter was used for BC measurements of ALADINA profiles, except for the model comparison in Sect. 3.3. The simulations were run prior to the statistical overview in Sect. 3.1 with a span of $1 \mathrm{~s}$. 


\subsection{Model description of COSMO-ART for DACCIWA}

In this section, a short description of the model COSMOART (Consortium for Small-scale Modelling-Aerosols and Reactive Trace gases) is shown with respect to the simulation set-up for the DACCIWA measurement campaign. COSMOART is a comprehensive online coupled model system (Vogel et al., 2009) based on the operational weather forecast model COSMO (Baldauf et al., 2011). COSMO-ART includes a comprehensive chemistry module to describe the gaseous composition of the atmosphere and secondary aerosol formation. Chemical reactions are calculated with RADMKA (Regional Acid Deposition Model Version Karlsruhe; Vogel et al., 2009), which is based on RADM2 (Regional Acid Deposition Model; Stockwell et al., 1990). Physical processes, including transport, turbulent diffusion, and dry and wet deposition, are treated together with photochemistry and aerosol dynamics using the modal approach. The size distribution of aerosol within COSMO-ART is approximated by $11 \mathrm{log}$ normal distributions (modes), considering the Aitken and nucleation mode (with and without BC core), fresh BC, and the coarse mode (sea salt and mineral dust). COSMO-ART explicitly treats the ageing of $\mathrm{BC}$ particles by transferring them from external to internal mixtures as described in Riemer et al. (2004). For DACCIWA, the COSMO-ART model system was applied quasi-operationally during the DACCIWA measurement campaign to support decision-making related to research aircraft flight tracks within the aircraft special observing period (27 June-17 July 2016) and to derive model climatologies of the spatial distribution of southern West African air pollution. More details of the model set-up for DACCIWA can be taken from Deetz et al. (2018). The continuous forecasts were initiated on 8 May and were active until 31 July 2016 , covering the simulation domain $25^{\circ} \mathrm{W}-$ $40^{\circ} \mathrm{E}$ and $20^{\circ} \mathrm{S}-35^{\circ} \mathrm{N}$ with a grid mesh size of $28 \mathrm{~km}$ and $3 \mathrm{~h}$ model output. ICON forecasts were used as meteorological boundary conditions and MOZART (Model for OZone and Related chemical Tracers) as aerosol-chemistry boundaries. The simulations consider the emission of mineral dust, sea salt, biogenic volatile organic compounds, dimethyl sulfide, and emissions of biomass burning and anthropogenic origin. Thus, $\mathrm{BC}$ is related to anthropogenic emissions and emissions from biomass burning. But feedbacks of the prognostic aerosol on the aerosol direct and indirect effect are not considered in these simulations.

\subsection{Measurement site}

The measurement flights were performed at the local airfield $\left(8^{\circ} 1^{\prime} \mathrm{N}, 2^{\circ} 27^{\prime} \mathrm{E}\right.$; $185 \mathrm{~m}$ a.s.l. $)$ south-west of Savè, Benin, in the period between 2 and 16 July 2016. The commune covers an area of $2 \times 10^{4} \mathrm{~km}^{2}$ with approximately $100000 \mathrm{in}$ habitants. The Savè supersite of the Karlsruhe Institute of Technology (KIT) and Université de Toulouse (Université de Toulouse III-Paul Sabatier, UPS) was installed at a dis-

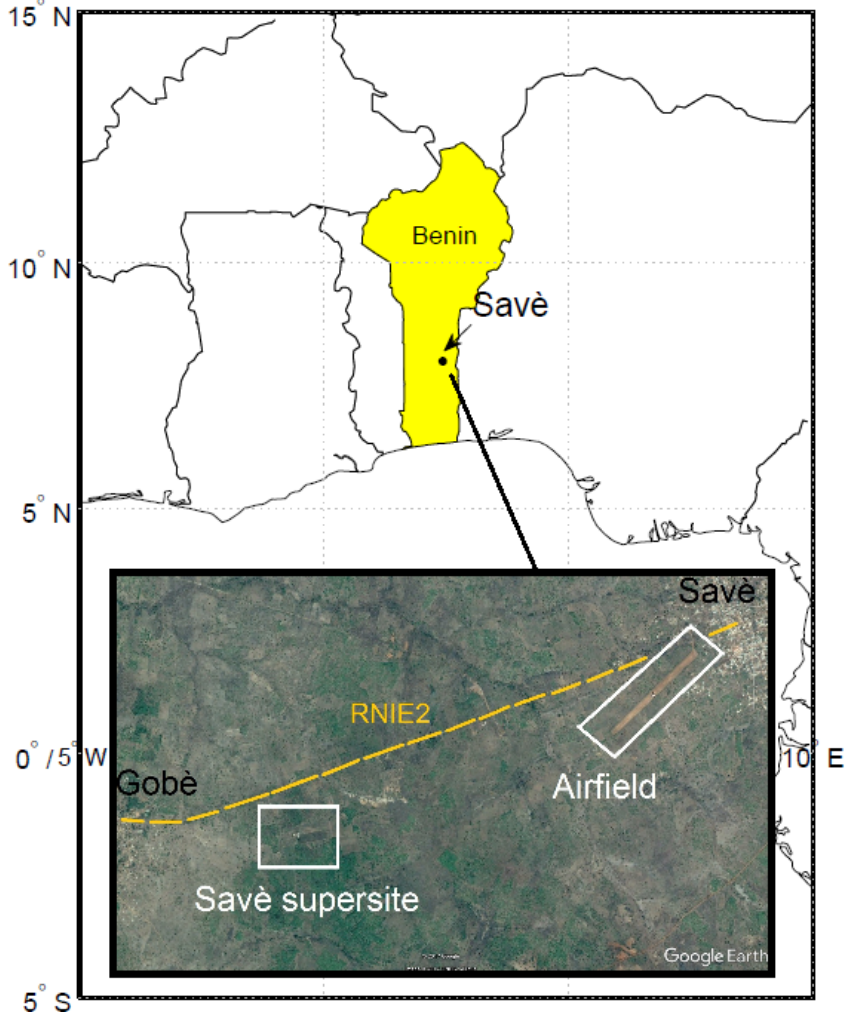

Figure 4. The map shows the position of the measurement site Savè in Benin (marked in yellow), West Africa. The UAS ALADINA was operated at the local airfield of Savè during the field experiment DACCIWA from 2 until 16 July 2016. The Savè supersite of the Karlsruhe Institute of Technology (KIT) and Université de Toulouse III-Paul Sabatier (UPS) was located in the south-west with a distance of $4 \mathrm{~km}$ to the airfield. The sites are connected via the main road RNIE2 (dashed yellow line). The picture was created with Google Earth@ on 28 April 2017.

tance of $4 \mathrm{~km} \mathrm{SW}$ of the airfield close to Gobè (Fig. 4). An overview of the Savè supersite and mounted instrumentation is given in Kalthoff et al. (2018). Both measurement sites are connected with the main road RNIE2. The airfield consists of dry and sandy soils and is surrounded by agricultural land. During the experiment, 53 flights were performed during different time periods of the day with a total flight duration of $32 \mathrm{~h}$ and a total flight distance of approximately $2260 \mathrm{~km}$. Within the study, 155 vertical profiles were realised up to a maximum height of $1600 \mathrm{~m}$ a.g.l., allowing for the analysis of ABL conditions in connection with the vertical distribution of BC. Although the Savè supersite was at a distance of $4 \mathrm{~km}$, horizontal flights were in most cases directed parallel to the current wind direction measured at the supersite.

\subsubsection{Ceilometer and wind profiler}

In order to retrieve information on cloud cover, cloud base height, wind speed, and wind direction during the UAS oper- 
ation, ceilometer and wind profiler data were used from the Savè supersite.

The CHM15k ceilometer was employed to obtain the temporal evolution of cloud characteristics during the DACCIWA campaign (Handwerker et al., 2016). From the measurements of the attenuated backscatter coefficient profiles, the cloud base height is determined based on a threshold method (manufacturer Lufft, personal communication, 2016). The manufacturer algorithm allows for the detection of up to three cloud base heights at a temporal resolution of $1 \mathrm{~min}$ and $15 \mathrm{~m}$ vertical resolution. In this study, only the first detected cloud base height is shown, since the focus is on low-level clouds.

High-resolution information on flow conditions (wind speed and wind direction) is obtained from a sodar (for the lower part of the ABL; Wieser et al., 2016) and ultra-highfrequency (UHF) wind profiler (above $200 \mathrm{~m}$ a.g.1.) measurements.

The sodar is an active remote sensing instrument, which was continuously running during the campaign. The retrieved information is based on the reflection of acoustic pulses at temperature inhomogeneities in the air with subsequent Doppler analysis. The instrument provides profiles of horizontal wind speed and direction as well as the backscatter at $30 \mathrm{~min}$ temporal resolution and $10 \mathrm{~m}$ vertical resolution between 30 and $600 \mathrm{~m}$ a.g.l. in altitude.

The UHF wind profiler installed at the Savè supersite by UPS is a $1274 \mathrm{MHz}$ Doppler radar, and it works with five beams to document the vertical structure of atmospheric dynamics up to the middle troposphere. It allows for the retrieval of the three wind components. The wind profiler operated continuously from 19 June to 30 July 2016 with two acquisition modes (75 and $150 \mathrm{~m}$ vertical resolution, respectively) at a time resolution of $2 \mathrm{~min}$. This radar is used in Dione et al. (2019) for the characterisation of low-level atmosphere dynamics during the whole DACCIWA campaign. More details on the data availability and technical characteristics of this radar can be found in Derrien et al. (2016). In this study, the data were averaged over $15 \mathrm{~min}$ using the low mode $(0-3 \mathrm{~km})$ for the analysis of wind speed and wind direction during the studied days.

\subsubsection{Gas concentrations of $\mathrm{NO}_{x}$ and $\mathrm{CO}$}

Measurements of trace gases were taken on two separate towers. Nitrogen monoxide (NO) and nitrogen dioxide $\left(\mathrm{NO}_{2}\right)$ were measured on an $8 \mathrm{~m}$ high tower, and carbon monoxide (CO) was measured separately at $3.5 \mathrm{~m}$. Both towers were located at the Savè supersite, $80 \mathrm{~m}$ away from each other, and were generally upwind from the main neighbouring town of Savè and the power generator used for the whole instrumentation.

$\mathrm{CO}$ atmospheric mixing ratios were measured with a modified model 48C-TL CO analyser (Thermo Environmental Instruments Inc.) with a detection limit of $12 \mathrm{ppb}_{\mathrm{v}}$. A dynamic dilution method by flow regulators is used for the $\mathrm{CO}$ calibration. The dilution is made with a commercial reference CO$\mathrm{N}_{2}$ mix at $450 \mathrm{ppm}_{\mathrm{v}}$ (air liquid bottle) into zero air made by Sofnocat 423 . Every 3 or 4 years, the flow regulator device is sent to the French Laboratoire national d'Essais for check and calibration.

$\mathrm{NO}$ and $\mathrm{NO}_{2}$ were measured with a model 42C-TL NO$\mathrm{NO}_{2}-\mathrm{NO}_{x}$ (Thermo Environmental Instruments Inc.) with a $0.05 \mathrm{ppb}_{\mathrm{v}}$ detection limit. The model 42C-TL NO-NO $\mathrm{N}_{2}-$ $\mathrm{NO}_{x}$ was calibrated before and after the campaign by using a reference $\mathrm{NO}_{2}$ air mixture, i.e. $\mathrm{NO}$ in $\mathrm{N}_{2}$ diluted with zero air. Reference $\mathrm{NO}$ and $\mathrm{NO}_{2}$ were ISO 6141:2015 certified at 8.73 and 8.58 ppm for $\mathrm{NO}$ before and after the campaign, respectively, and $9.28 \mathrm{ppm}$ for $\mathrm{NO}_{2}$, both with $5 \%$ precision (Pacifico et al., 2019).

All data for the trace gases were sampled every $10 \mathrm{~s}$, filtered, and averaged to produce 1 and 30 min values. The data are accessible from Derrien et al. (2016).

\section{Results and discussion}

First, an overview is presented with respect to the small-scale vertical variability of BC that was measured with ALADINA during the 2-week period (2-16 July 2016) of DACCIWA. Further, a particular case (14-15 July 2016) is analysed in detail that shows enhanced layers of BC which are not issued from primary emissions. This is subsequently supported by comparison with ground data on gas concentrations and model results of COSMO-ART. During the case study, weather conditions were typical for the WAM, mainly influenced by the occurrence of a low-level jet and low-level clouds, which are shown with ground-based monitoring by a wind profiler and ceilometer. Thus, the observations shown here might be reproducible for other investigation periods in the WAM season.

\subsection{Summary of the vertical variability of BC during the experiment}

Figure 5a shows the BC mass concentration, potential temperature, and water vapour mixing ratio calculated in $20 \mathrm{~m}$ intervals in the lowermost $1100 \mathrm{~m}$ a.g.l. along 155 vertical profiles. Figure $5 \mathrm{~b}$ presents the standard deviation of the mean profiles for the corresponding parameters shown in Fig. 5a. The vertical distribution of the minimum BC mass concentration was almost not detectable in the lowermost $600 \mathrm{~m}$ a.g.1., but it increased up to $1.64 \pm 0.2 \mu \mathrm{g} \mathrm{m}^{-3}$ at higher altitudes. The total maximum of $14.01 \mu \mathrm{g} \mathrm{m}^{-3}$ was measured at the height of $200 \mathrm{~m}$ a.g.l. but was only observed during $1 \mathrm{~d}$ on 15 July 2016. The mean BC mass concentration $(\overline{\mathrm{BC}})$ varied between 1.79 and $2.42 \mu \mathrm{g} \mathrm{m}^{-3}$, and the standard deviation for all altitude intervals was $\pm 0.31 \mathrm{~g} \mathrm{~m}^{-3}$. The vertical distribution of $\overline{\mathrm{BC}}$ showed three dominant distinguished layers at the heights of 200, 600 and $920 \mathrm{~m}$ a.g.1. (Fig. 5b). 
The mean potential temperature $(\bar{\theta})$ was between 300.6 and $304.1 \mathrm{~K}$ in the vertical distribution and represented an overall stable stratification of the ABL, as the majority of the measurement flights were performed in the morning hours. The mean water vapour mixing ratio $(\bar{q})$ varied between 14.24 and $16.24 \pm 0.52 \mathrm{~g} \mathrm{~kg}^{-1}$ and decreased with altitude in the lowermost $1100 \mathrm{~m}$ a.g.l.

All mean values showed a sharp gradient at the height of $600 \mathrm{~m}$ a.g.l. One explanation for this could be less data availability above this height. The research flights are restricted below cloud base, as ALADINA is not rainproof. The first part of the measurement period (2-8 July 2016) was during the post-onset phase of the WAM season (Knippertz et al., 2017). This period was influenced by low-level clouds with a median height of cloud top at $587 \mathrm{~m}$ a.g.l., taken from 06:00 UTC radiosondes at Savè (Kalthoff et al., 2018). This part corresponds to almost half (25 of 53) of the research flights. Although nocturnal low-level clouds dissolved during the day, a large portion of the vertical profiles still remained below $600 \mathrm{~m}$ a.g.l. Drier periods occurred during the vortex phase of the WAM that was predominant from 9 until 17 July 2016 (Knippertz et al., 2017).

Taken from the statistical overview of $\overline{\mathrm{BC}}, \mathrm{BC}$ seems to occur in the whole ABL. No clear evidence is visible for local pollution near the surface. One explanation could be the performance of ALADINA during daytime so that in some cases the ABL was already well mixed and $B C$ was lifted from the ground through the ABL. However, this cannot be supported by $\bar{\theta}$, which shows an overall stable ABL. This relationship presumes that observed $\mathrm{BC}$ originated prior to the observation periods, probably during night or even earlier. Another possibility could be horizontal advection that caused distinguished layers of $\mathrm{BC}$ in the ABL. Here, the understanding of $\mathrm{BC}$ in the $\mathrm{ABL}$ cannot be fully described by previous observations like Wilcox et al. (2016) and Liu et al. (2018). Directly emitted BC would have probably warmed the ABL by absorption, which further caused stable conditions and a lower ABL height but with increased humidity. This is in contrast to the reduced humidity observed here due to the decline of $\bar{q}$ in the ABL. Therefore, it is essential to take into account other aspects that might affect the $\mathrm{BC}$ distribution within the ABL.

\subsection{BC observations during case study on 14-15 July 2016}

The following section addresses the vertical distribution of BC measured with ALADINA on $2 \mathrm{~d}$ in this period (14 and 15 July 2016). The first day was influenced by a nocturnal low-level jet and free of low-level clouds. The second day was affected by a nocturnal low-level jet and by the presence of low-level clouds; see Babić et al. (2019a).

An overview of the measurements performed with ALADINA is presented in Table 1. The flight time of ALADINA is given in UTC (local time $=$ UTC $+01: 00$ ). In ad- dition, gas concentrations of $\mathrm{NO}_{x}$ and $\mathrm{CO}$ (Derrien et al., 2016) are presented for the flight periods as $1 \mathrm{~min}$ averages. The total maximum $\mathrm{NO}_{x}$ concentration of $1.9 \mathrm{ppb}_{\mathrm{v}}$ was observed in the morning between 06:41 and 08:40 UTC on 15 July 2016 simultaneously with the maximum CO concentration of $259 \mathrm{ppb}_{\mathrm{v}}$.

Backscatter data indicate that there was a well-mixed layer in the afternoon on 14 July 2016, and low-level clouds appeared temporarily above $800 \mathrm{~m}$ a.g.l. (Fig. 6a). On the following day, low-level clouds formed below $250 \mathrm{~m}$ a.g.l. at about 07:00 UTC (Fig. 6b). The enhanced aerosol load disappeared, which can be seen by the enhanced backscatter at an altitude up to $300 \mathrm{~m}$ a.g.l. from midnight to 07:00 UTC in Fig. 6b. Afterwards, the clouds lifted up to $750 \mathrm{~m}$ a.g.l. at 11:00 UTC and dissolved completely at 14:00 UTC in the lowermost $2 \mathrm{~km}$ a.g.l. In addition, a second layer of clouds built up at the height between 1050 and $2000 \mathrm{~m}$ a.g.l.

Wind conditions are shown in Fig. 7. The wind speed was moderate between 3 and $6 \mathrm{~m} \mathrm{~s}^{-1}$ in the lowermost $2 \mathrm{~km}$ a.g.l. in the night from 13 July until the early morning at 06:00 UTC on 14 July (Fig. 7a). The observed low-level jet intensified in the course of the night and reached the maximum speed in the early morning hours. The strip of high wind speed had dissolved at midday, simultaneously with the occurrence of clouds. However, in the afternoon, there was a low-level wind maximum of 6-8 $\mathrm{m} \mathrm{s}^{-1}$ at the height between 200 and $600 \mathrm{~m}$ a.g.l. that persisted for more than $12 \mathrm{~h}$ at the same altitude (Fig. 7b). At 07:00 UTC on 15 July, when lowlevel clouds were present, the wind speed reached a maximum of $9 \mathrm{~m} \mathrm{~s}^{-1}$ between the height of 800 and $1000 \mathrm{~m}$ a.g.l. After the dissolving cloudiness at 12:00 UTC, a wind speed of $3 \mathrm{~m} \mathrm{~s}^{-1}$ was observed. Measured wind speed and wind direction are a combination of the persistent monsoon flow and the maritime inflow that typically arrives in the early evening hours (Dione et al., 2019; Adler et al., 2019).

Figure $8 \mathrm{a}$ displays three vertical profiles between the height of 100 and $800 \mathrm{~m}$ a.g.l. obtained with ALADINA at 06:15, 06:55, and 07:27 UTC on 14 July 2016. The ABL was stably stratified with the base of the inversion layer at $400 \mathrm{~m}$ a.g.l. At the heights of 450 to $500 \mathrm{~m}$ a.g.l. a dry air mass was observed, as can be seen from the profile of the water vapour mixing ratio. Above the inversion layer and in accordance with the different type of air mass, an increase in $\mathrm{BC}$ was observed in the residual layer. The total maximum $\mathrm{BC}$ of $2.75 \mu \mathrm{g} \mathrm{m}^{-3}$ was measured at the height of $600 \mathrm{~m}$ a.g.l. in the first profile at 06:15 UTC. The enhanced BC concentration at this altitude was still visible $1 \mathrm{~h}$ later. The wind direction varied between SE and SW, and the vertical distribution of the wind speed showed a significant increase close to the inversion layer. At 07:27 UTC the wind speed increased up to $12 \mathrm{~m} \mathrm{~s}^{-1}$ between the height of 400 and $500 \mathrm{~m}$ a.g.l.

The structure of the ABL was well mixed at noon and before the evening transition (Fig. 8b), leading to homogeneous conditions of $q$ and $\mathrm{BC}$ in the vertical distribution. The wind direction changed from SW to SE in the lower- 
(a) Calculation of 155 vertical profiles during DACCIWA from 2 until 16 July 2016
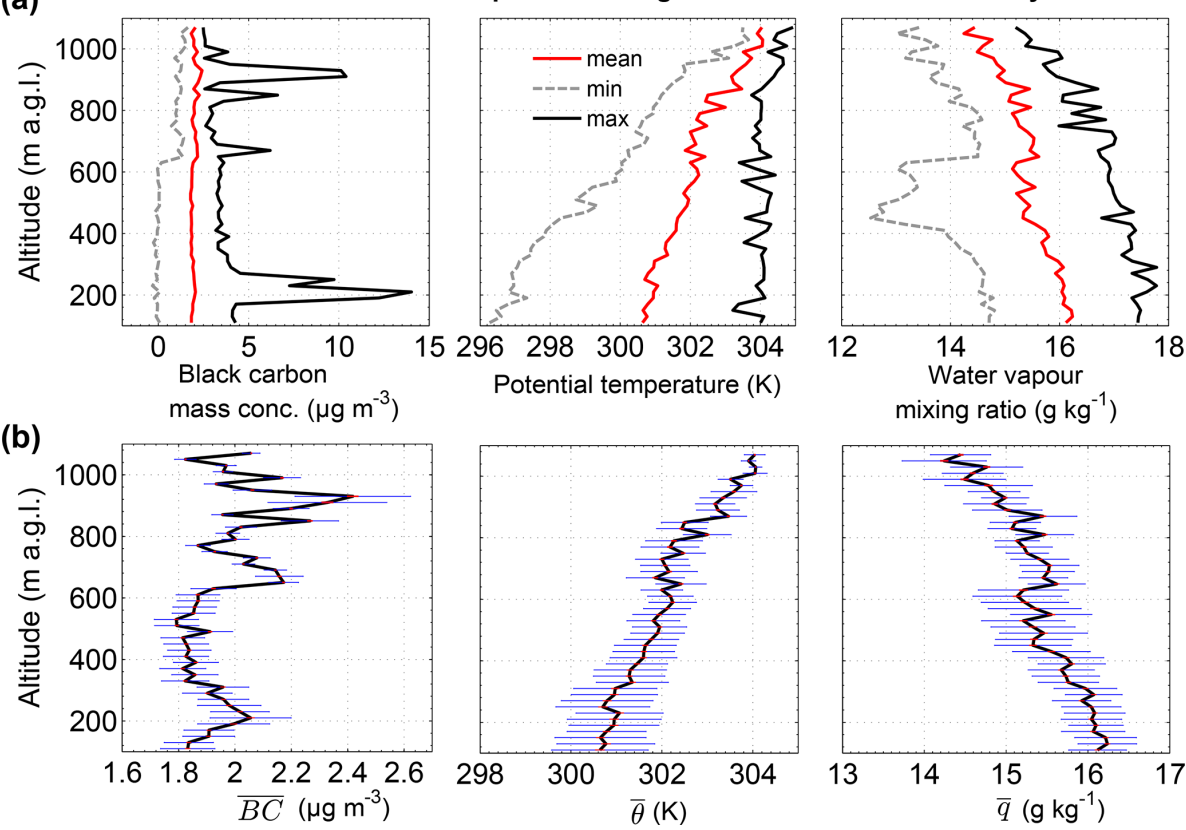

Figure 5. Summary of 155 vertical profiles from 100 to $1100 \mathrm{~m}$ a.g.l. measured with ALADINA during the field experiment of DACCIWA on 2-16 July 2016. (a) Vertical profiles of black carbon mass concentration (BC) measured with the aethalometer and $10 \mathrm{~s}$ low-pass filtering, potential temperature $\theta$, and water vapour mixing ratio $q$. The red line represents the mean value, the grey dashed line stands for the total minimum, and the solid black line is the total maximum of all vertical profiles averaged in $20 \mathrm{~m}$ altitude intervals. (b) The mean values of $\mathrm{BC}(\overline{\mathrm{BC}}), \theta(\bar{\theta})$, and $q(\bar{q})$ in $20 \mathrm{~m}$ steps and the corresponding standard deviation for each height interval.

Table 1. Measurements performed with the UAS ALADINA during DACCIWA on 14-15 July 2016. The table presents the flight time in UTC, cloudy conditions indicated by the lowest cloud base, and gas concentration variations of $\mathrm{NO}_{x}$ and $\mathrm{CO}$ during the corresponding flight time as a possible indicator for local emissions (sampled at the Savè supersite by UPS).

\begin{tabular}{lrrrrr}
\hline $\begin{array}{l}\text { Flight } \\
\text { number }\end{array}$ & $\begin{array}{r}\text { Day in } \\
\text { July } 2016\end{array}$ & $\begin{array}{r}\text { Flight time } \\
\text { take-off-landing }\end{array}$ & Cloud base & $\mathrm{NO}_{x}$ & $\mathrm{CO}$ \\
\hline 1 & 14 & $05: 28-06: 19$ UTC & $1200 \mathrm{~m}$ & $0.7-1.1 \mathrm{ppb}_{\mathrm{v}}$ & $158-231 \mathrm{ppb}_{\mathrm{v}}$ \\
2 & 14 & $06: 51-07: 32$ UTC & $>2000 \mathrm{~m}$ & $0.6-0.8 \mathrm{ppb}_{\mathrm{v}}$ & $162-195 \mathrm{ppb}_{\mathrm{v}}$ \\
3 & 14 & $11: 03-11: 43$ UTC & $1000 \mathrm{~m}$ & $0.7-1.8 \mathrm{ppb}_{\mathrm{v}}$ & $153-203 \mathrm{ppb}_{\mathrm{v}}$ \\
4 & 14 & $12: 07-12: 56 \mathrm{UTC}$ & $800 \mathrm{~m}$ & $0.6-0.8 \mathrm{ppb}_{\mathrm{v}}$ & $146-208 \mathrm{ppb}_{\mathrm{v}}$ \\
5 & 14 & $16: 42-17: 23 \mathrm{UTC}$ & $1000 \mathrm{~m}$ & $0.9-1.5 \mathrm{ppb}_{\mathrm{v}}$ & $179-218 \mathrm{ppb}_{\mathrm{v}}$ \\
6 & 14 & $17: 42-18: 24 \mathrm{UTC}$ & $>2000 \mathrm{~m}$ & $1.0-1.7 \mathrm{ppb}_{\mathrm{v}}$ & $189-232 \mathrm{ppb}_{\mathrm{v}}$ \\
7 & 15 & $05: 27-06: 13 \mathrm{UTC}$ & $1700 \mathrm{~m}$ & $1.0-1.3 \mathrm{ppb}_{\mathrm{v}}$ & $214-249 \mathrm{ppb}_{\mathrm{v}}$ \\
8 & 15 & $06: 41-07: 24 \mathrm{UTC}$ & $300 \mathrm{~m}$ & $1.4-1.9 \mathrm{ppb}_{\mathrm{v}}$ & $224-259 \mathrm{ppb}_{\mathrm{v}}$ \\
9 & 15 & $08: 00-08: 40$ UTC & $400 \mathrm{~m}$ & $1.4-1.9 \mathrm{ppb}_{\mathrm{v}}$ & $203-239 \mathrm{ppb}_{\mathrm{v}}$ \\
10 & 15 & $16: 48-17: 22$ UTC & $>2000 \mathrm{~m}$ & $0.8-1.4 \mathrm{ppb}_{\mathrm{v}}$ & $156-194 \mathrm{ppb}_{\mathrm{v}}$ \\
11 & 15 & $17: 40-18: 22$ UTC & $>2000 \mathrm{~m}$ & $1.1-1.3 \mathrm{ppb}_{\mathrm{v}}$ & $180-215 \mathrm{ppb}_{\mathrm{v}}$ \\
\hline
\end{tabular}

most $200 \mathrm{~m}$ a.g.l., and the wind speed was constant at $5 \mathrm{~m} \mathrm{~s}^{-1}$ in the lowermost $800 \mathrm{~m}$ a.g.l.

On the following day (15 July 2016) the ABL was influenced by the formation of low-level clouds around 07:00 UTC. The same parameters as shown in the previous part are presented in Fig. 9. In this case, three vertical profiles are displayed at 05:33, 06:10, and 06:46 UTC before low-level clouds occurred. The UAS was operated between 100 and $900 \mathrm{~m}$ a.g.l. and the ABL was stable with a capping inversion layer at $300-400 \mathrm{~m}$ a.g.l. The fourth vertical profile was performed at 08:29 UTC below the cloud base maximum height of $320 \mathrm{~m}$ a.g.l. The last profile was carried out at 16:52 UTC after the dissolution of low-level clouds below $650 \mathrm{~m}$ a.g.l. The ABL was well mixed and $q$ decreased in comparison with the profiles in the morning hours. BC decreased to $1.5 \mu \mathrm{g} \mathrm{m}^{-3}$ at the height of $300 \mathrm{~m}$ a.g.l. One explanation could be wash-out by low-level clouds. BC reduction might also be caused by the change in wind direction to 
(a)

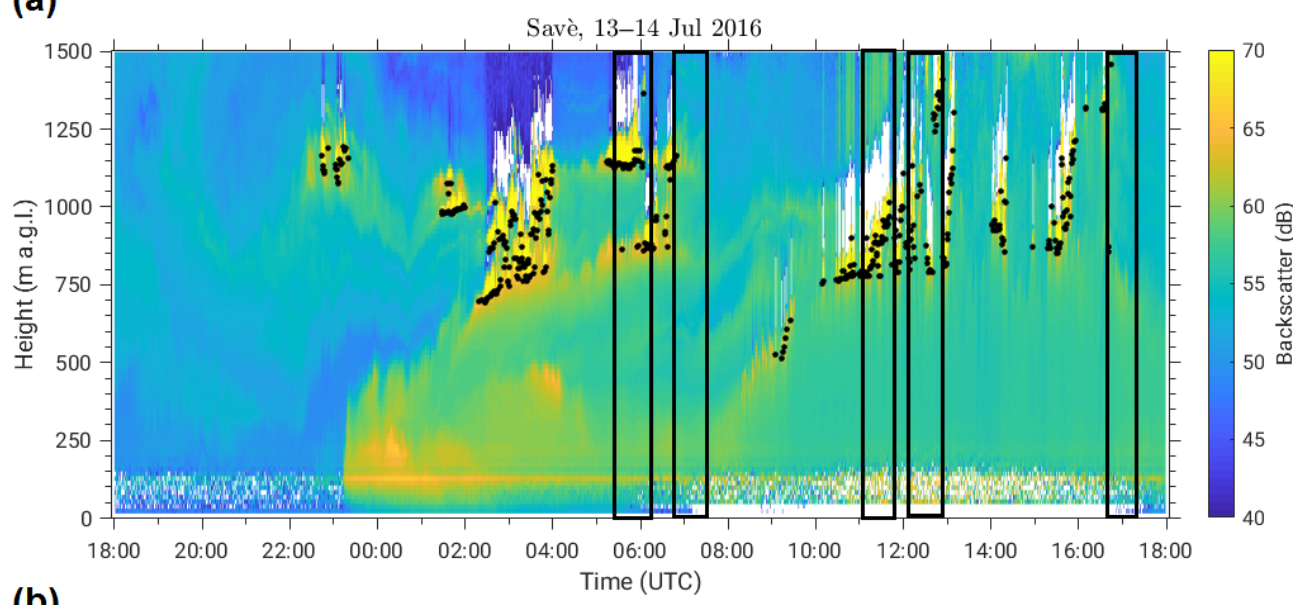

(b)

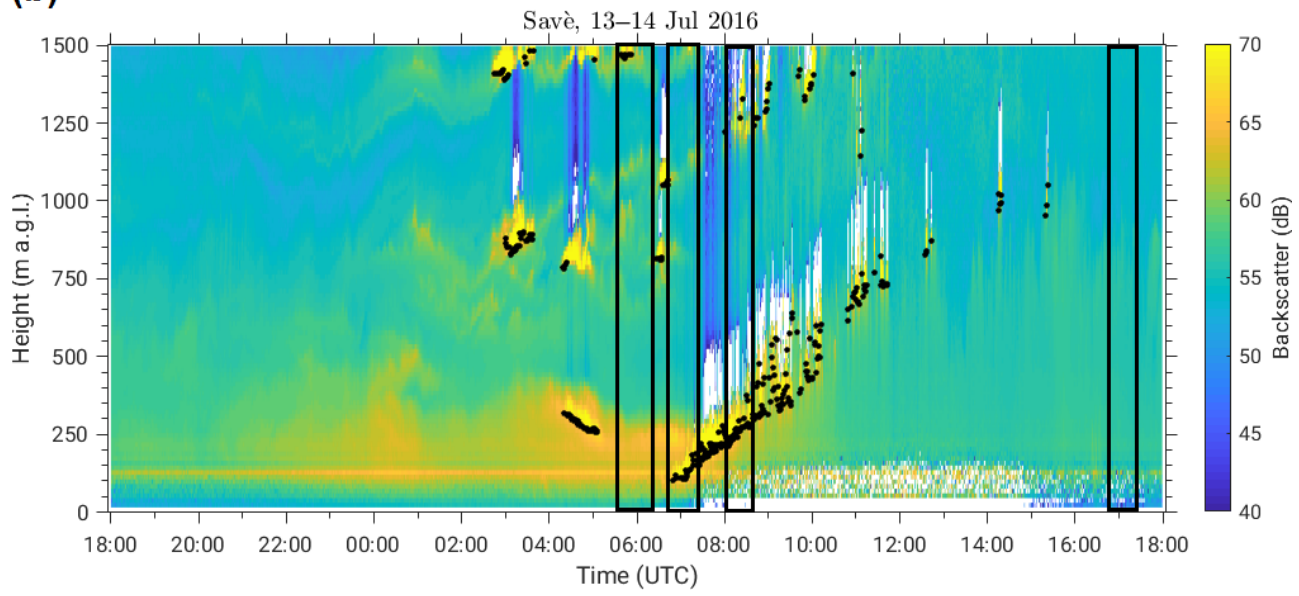

Figure 6. Backscatter signal of the KIT ceilometer (Handwerker et al., 2016) installed at the Savè supersite between (a) 18:00 UTC on 13 July 2016 and 18:00 UTC on 14 July 2016 as well as (b) in the period of 18:00 UTC on 14 July 2016 to 18:00 UTC on 15 July 2016. On 14 July, different layers of atmospheric particles were observed during the day. At midday, clouds were detected at $800 \mathrm{~m}$ a.g.l. and dissolved at 18:00 UTC. On 15 July, low-level clouds occurred at 07:00 UTC in the lowermost $200 \mathrm{~m}$ a.g.l., lifted up to the height of 750 ma.g.1. at 11:00 UTC, and dissolved in the afternoon at 14:00 UTC in the lowermost $1.5 \mathrm{~km}$. The black boxes indicate the flight periods of the UAS ALADINA.

SSW. Probably, a different type of air mass with cleaner air was observed in the investigation area. The wind speed increased close to ground level up to $5 \mathrm{~m} \mathrm{~s}^{-1}$ but decreased to $3.2 \mathrm{~m} \mathrm{~s}^{-1}$ at $600 \mathrm{~m}$ a.g.l.

\subsection{Comparison of ALADINA observations with COSMO-ART model results}

In this section, ALADINA BC profiles are compared with the model results of COSMO-ART obtained during the case study. For the comparison it has to be considered that COSMO-ART has a grid mesh size of $28 \mathrm{~km}$ and the lowest $1000 \mathrm{~m}$ is resolved by only 11 layers. This makes a direct comparison with airborne point observations difficult. Nevertheless, the simulations with COSMO-ART provide added value to this study: $\mathrm{BC}$ can be separated into fresh $\mathrm{BC}$, aged $\mathrm{BC}$ in the Aitken mode, and aged $\mathrm{BC}$ in the accumulation mode, allowing us to discuss potential sources of BC. Further, simulations allow us to embed the local observations into larger spatial scales. Riemer et al. (2004) indicated BC ageing timescales of $8 \mathrm{~h}$ close to source regions and $2 \mathrm{~h}$ above source regions for daytime conditions during summer, predominantly related to ageing via the condensation of sulfuric acid on BC particles.

Figure 10 shows the spatio-temporally collocated total BC profiles of ALADINA with $1 \mathrm{~Hz}$ temporal resolution and COSMO-ART for six different time intervals. In addition, the COSMO-ART results for fresh BC, aged BC (Aitken mode), and aged $\mathrm{BC}$ (accumulation mode) are indicated.

For 14 July 2016 (see Fig. 10a-d) a full diurnal cycle of $\mathrm{BC}$ profiles from 06:00 to 18:00 UTC is presented. In the morning hours the observations show increased concentrations above $500 \mathrm{~m}$ a.g.l., with a peak of around $3.0 \mu \mathrm{g} \mathrm{m}^{-3}$ at $600 \mathrm{~m}$ a.g.l. (Fig. 10a). This peak is represented in the 


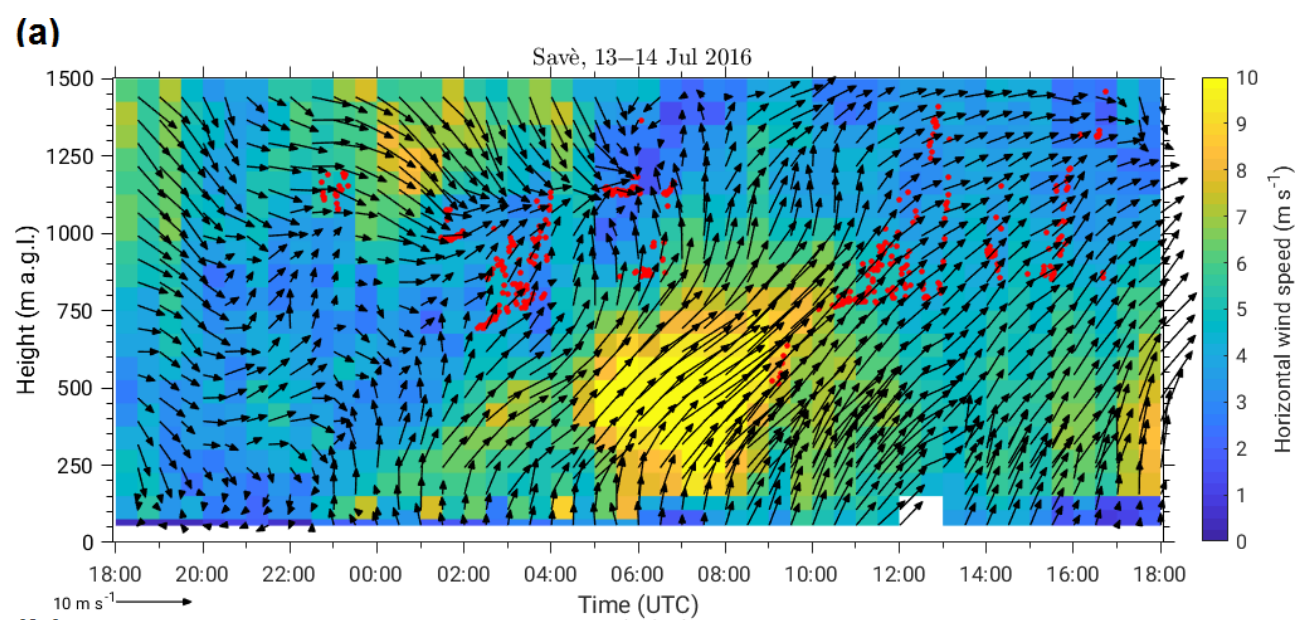

(b)
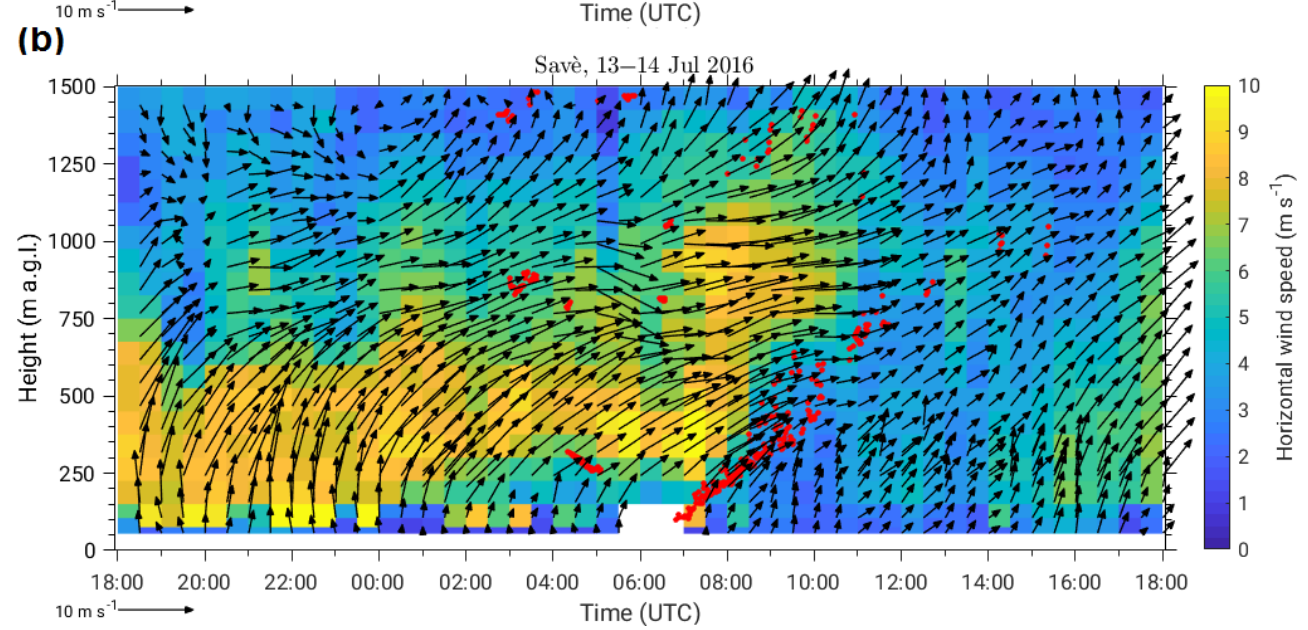

Figure 7. Time series of the wind speed and the wind direction at the Savè supersite during DACCIWA (Derrien et al., 2016). The wind speed is indicated in the colour bar and the direction with arrows (a leftwards horizontal arrow stands for wind direction from the east; an arrow from bottom to top is for south wind). The wind speed in the lowermost $1.5 \mathrm{~km}$ was measured with the wind profiler of UPS from (a) 18:00 UTC on 13 July 2016 until 18:00 UTC on 14 July 2016 and (b) from 18:00 UTC on 14 July 2016 to 18:00 UTC on 15 July 2016. The red dots display the cloud base height measured with the ceilometer.

model. The best agreement is found for aged BC in the accumulation mode. However, COSMO-ART shows near-surface concentrations of up to $3 \mu \mathrm{g} \mathrm{m}^{-3}$ that are higher than the observations. Until noon, the vertical profile of $\mathrm{BC}$ shows a vertically constant $\mathrm{BC}$ concentration, likely due to vertical mixing in the ABL (Fig. 10b and c). COSMO-ART results of aged $\mathrm{BC}$ in the accumulation mode match these observations very well. The observed $\mathrm{BC}$ concentration peak at the altitude of $900 \mathrm{~m}$ a.g.l. is not seen by COSMO-ART and may be an artefact induced by the formation of cloud patches as seen by the ceilometer (Fig. 6a). Between 12:00 and 18:00 UTC, no significant change in the measured vertical $\mathrm{BC}$ profile is visible. In the simulations, the contribution of $\mathrm{BC}$ in the accumulation mode decreases and the concentration of $\mathrm{BC}$ in the Aitken mode increases, leading to better agreement of the observations with the total $\mathrm{BC}$ concentration (Fig. 10d). At 06:00 UTC on 15 July 2016 (see Fig. 10e) the observations and model indicate an enhanced BC con- centration below $400 \mathrm{~m}$ a.g.l. The vertical profile, capturing the lowest $900 \mathrm{~m}$ a.g.l., shows representative agreement of the observations and model on total BC. Around the height of $200 \mathrm{~m}$ a.g.l., ALADINA indicates high BC concentrations of more than $16 \mathrm{\mu g} \mathrm{m}^{-3}$ that are not represented in COSMOART. The discrepancy could be based on the $1 \mathrm{~s}$ sampling of ALADINA that is strongly noisy. The first assumption was turbulent mixing near the cloud edge that might have led to high variability of the sampling flow and thus BC data. Another possibility could be droplets that disturbed the signal. However, it cannot be ruled out that this is an artefact induced by high humidity prior to the onset of cloud formation, which occurred around that time. Finally, at 18:00 UTC, the observed $\mathrm{BC}$ profile corresponds to the aged $\mathrm{BC}$ in the accumulation mode.

Figure 11 shows a south-north cross section of the total $\mathrm{BC}$ concentration and wind speed up to an altitude of $1500 \mathrm{~m}$ a.g.l. for 14 July 2016 . The location of the airborne 


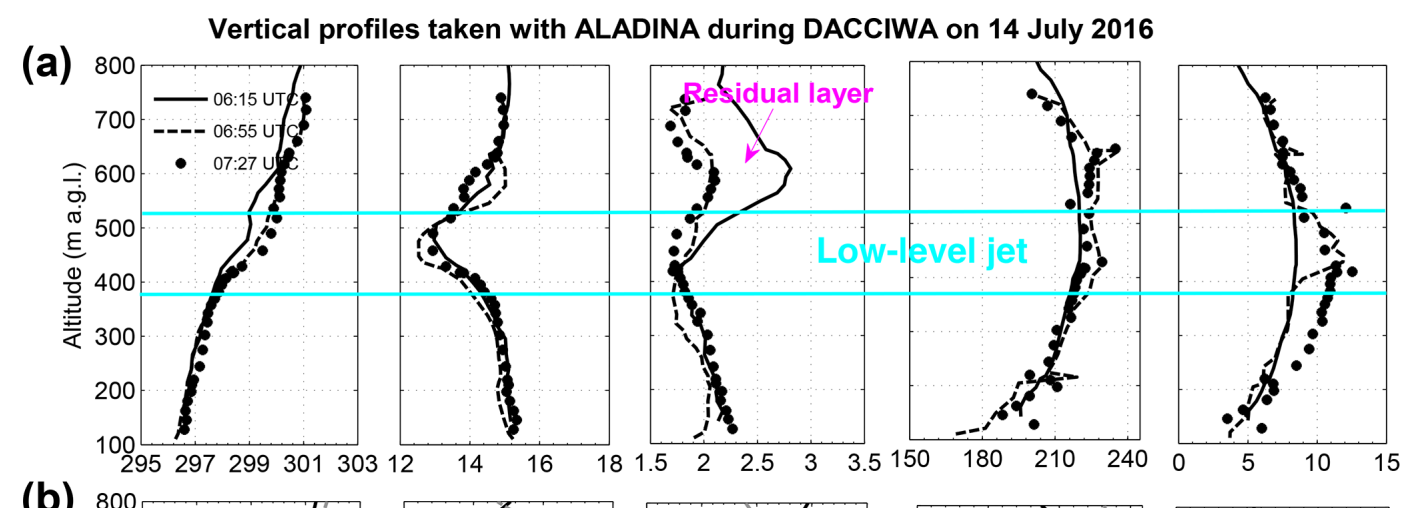

(b)

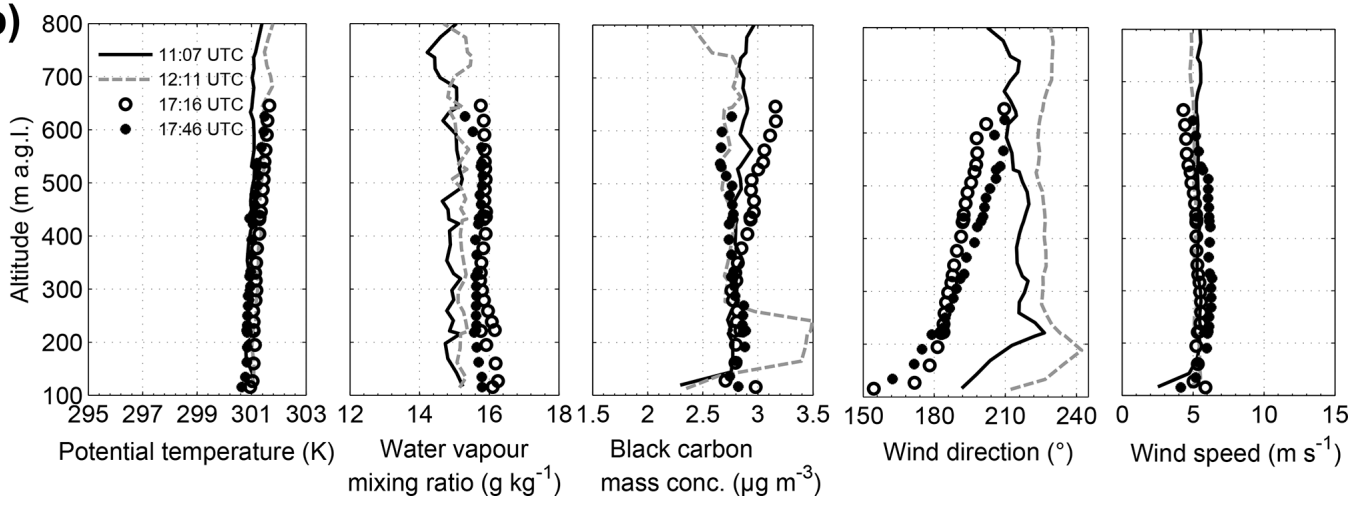

Figure 8. Vertical profiles taken with ALADINA between the height of 100 and $800 \mathrm{~m}$ a.g.1. on 14 July 2016. From left to right: potential temperature, water vapour mixing ratio, black carbon mass concentration, wind direction, and wind speed (a) in the morning from 06:15 until 07:27 UTC and (b) during cloud formation below the height of $800 \mathrm{~m}$ a.g.1. at 11:07 and 12:11 UTC as well as during the evening transition at 17:16 and 17:46 UTC. The horizontal turquoise line indicates the altitude range of the nocturnal low-level jet (see Fig. 7a).

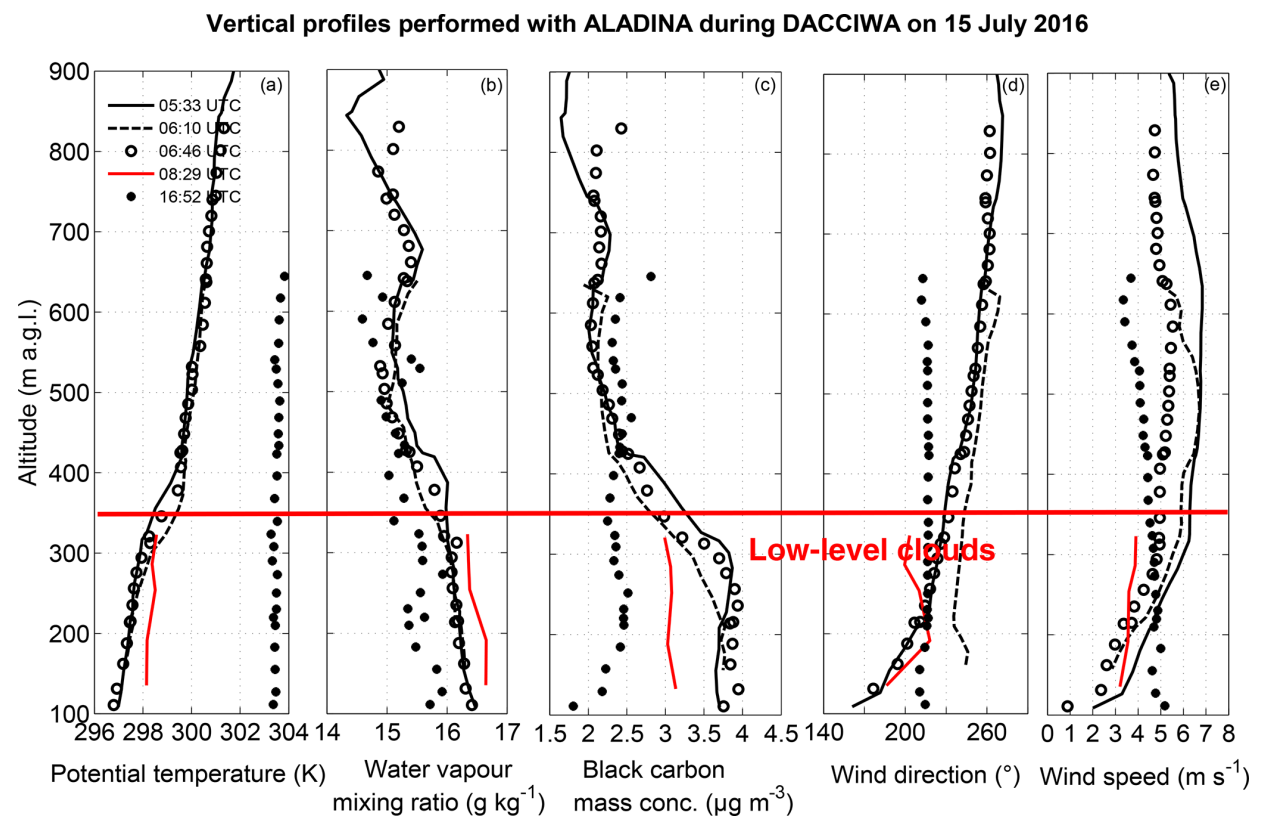

Figure 9. Five selected vertical profiles measured with ALADINA between the height of 100 and 900 m a.g.1. from 05:33 until 16:52 UTC on 15 July 2016. From left to right: potential temperature, water vapour mixing ratio, black carbon mass concentration, wind direction, and wind speed. The red horizontal line shows the altitude of low-level clouds formed at 07:00 UTC, derived from the backscatter signal of the ceilometer (see Fig. 6b). 

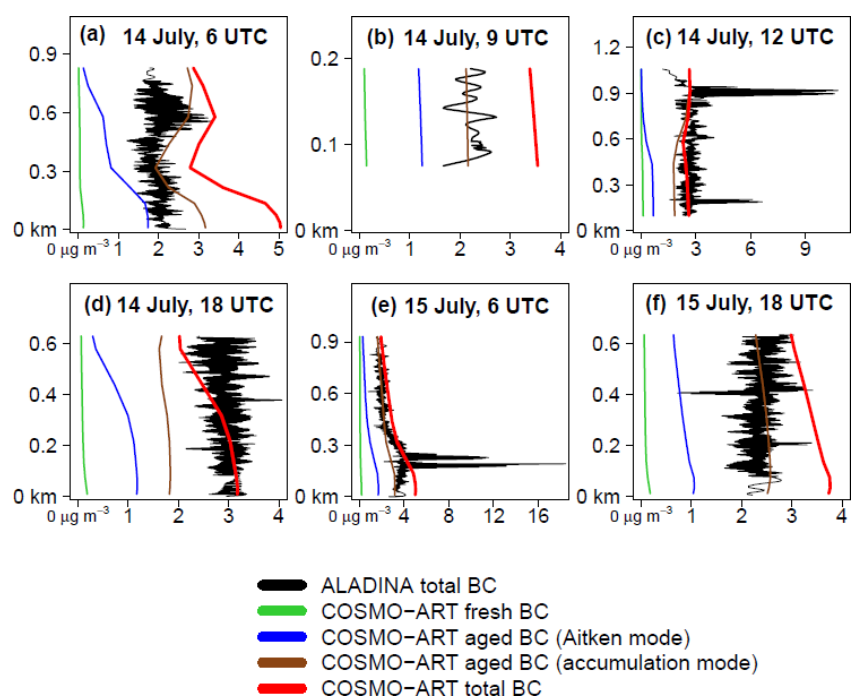

Figure 10. Vertical profiles of $\mathrm{BC}\left(\mu \mathrm{g} \mathrm{m}^{-3}\right)$ at Savè for (ad) 14 July 2016 and (e-f) 15 July 2016. The ALADINA observations of total $\mathrm{BC}$ are denoted in black; the COSMO-ART results for fresh BC, aged BC (Aitken mode), aged BC (accumulation mode), and total $\mathrm{BC}$ are shown in green, blue, brown, and red, respectively. The observations were temporally assigned to the 3-hourly model output with a deviation not larger than $1 \mathrm{~h}$ and by subsequently interpolating the model data to the ALADINA altitudes. Within these time steps, ALADINA conducted several ascents and descents. It is assumed that the observations within the time steps are measured instantaneously.

observations at Savè is indicated by the dashed line. The wind speed transect clearly shows the nocturnal low-level jet with its maximum around the height of $500 \mathrm{~m}$ a.g.l. From 13 July 2016 at 21:00 UTC until 14 July 2016 at 09:00 UTC, the jet propagates northwards. The vertical transect of the $\mathrm{BC}$ concentration indicates that the low-level jet is linked to lower BC concentrations, which were observed with ALADINA at 06:15 and 07:30 UTC on 14 July 2016 (Fig. 8) as well. The coastline is approximately at $6.2^{\circ} \mathrm{N}$, so the low $\mathrm{BC}$ concentrations occur especially over the Gulf of Guinea. In front of the jet, an air mass with a high $\mathrm{BC}$ burden (up to $20 \mu \mathrm{g} \mathrm{m}^{-3}$ near the surface) is visible. At 00:00 UTC, the BC concentration maximum is directly over Savè; however, this is not related to local emissions.

Three aspects seem to justify this hypothesis: (1) concentrations of $\mathrm{NO}_{x}$ and $\mathrm{CO}$ do not indicate anthropogenic local emissions for the observed time period. (2) Figure 10 shows negligible fractions of fresh $\mathrm{BC}$, which indicates less influence of local emissions. (3) By also considering the time steps before 13 July 2016 at 21:00 UTC, it becomes clear that the polluted air mass is transported from the south in front of the northward-propagating maritime inflow. Since the lowlevel jet has its maximum around $500 \mathrm{~m}$ in altitude, the clean air mass of the jet puts a wedge into the polluted air mass in front (e.g. visible on 14 July 2016 at 06:00 UTC). This leads to a near-surface pollution branch below the jet axis and an elevated pollution branch above the jet axis. This is also visible in the modelled profiles of Fig. 10a; in the observed profiles, a clearly enhanced $\mathrm{BC}$ concentration in the upper branch, a minimum at around $400-500 \mathrm{~m}$ a.g.1., and a slightly enhanced near-surface $\mathrm{BC}$ concentration are visible. At 12:00 UTC, the vertical mixing in the ABL leads to a rather homogeneous distribution of $\mathrm{BC}$ in the vertical profile. Even if the peak observed at 12:00 UTC around $900 \mathrm{~m}$ a.g.l. over Savè (see Fig. 10c) may be partly induced by cloud artefacts, its altitude corresponds to the location of the modelled elevated pollution branch in Fig. 11. From 14 July 2016 at 12:00 UTC on, the reestablishment of a pollution layer can be observed between 7 and $8^{\circ} \mathrm{N}$.

\section{Conclusions}

This article aims at understanding the relationship between the vertical distribution of $\mathrm{BC}$ and $\mathrm{ABL}$ processes in southern West Africa. The investigation area is supposed to be one of the major sources for BC emissions worldwide (Liousse et al., 2014). But where do those $\mathrm{BC}$ emissions originate, especially in the ABL? Beyond surface measurements, the role of $\mathrm{BC}$ is difficult to assess within the ABL due to lacking column measurements. ALADINA was applied for meteorological profiling and $\mathrm{BC}$ measurements during the extensive field experiment of DACCIWA at Savè, Benin, on 216 July 2016.

BC was measured with a micro-aethalometer, model AE51, that has proven to be a feasible tool on a UAS, but it suffers from artefacts that were one subject of this paper. Prior to analyses, BC data were corrected with bias caused by the dependence of the instrumentation on internal temperature during ascents and descents. Further, a low-pass filter was applied for the readings with a resolution of $10 \mathrm{~s}$.

For a statistical overview, BC was averaged for altitude intervals of $20 \mathrm{~m}$ steps along 155 vertical profiles of the whole measurement period. In contrast to initial expectations, no clear influence of primary $\mathrm{BC}$ emissions was observed in the vertical distribution. It was shown that $\mathrm{BC}$ occurred in the whole $\mathrm{ABL}$ and did not decrease depending on the altitude. Thus, the maxima and minima of the $\mathrm{BC}$ concentration could be caused by aspects other than ABL conditions. One explanation could relate to horizontal advection processes that might have brought about different types of air masses with distinguished layers of BC. Another explanation could be based on a regional scale. The measurement period was influenced by the WAM season, leading to a high occurrence of nocturnal low-level jets and low-level clouds that could have strongly affected the vertical distribution of $\mathrm{BC}$ due to dynamics in the ABL. (e.g. Dione et al., 2019; Kalthoff et al., 2018; Adler et al., 2019; Babić et al., 2019b).

One case study (14-15 July 2016) was presented in detail in order to clarify other possible impacts on the BC dis- 

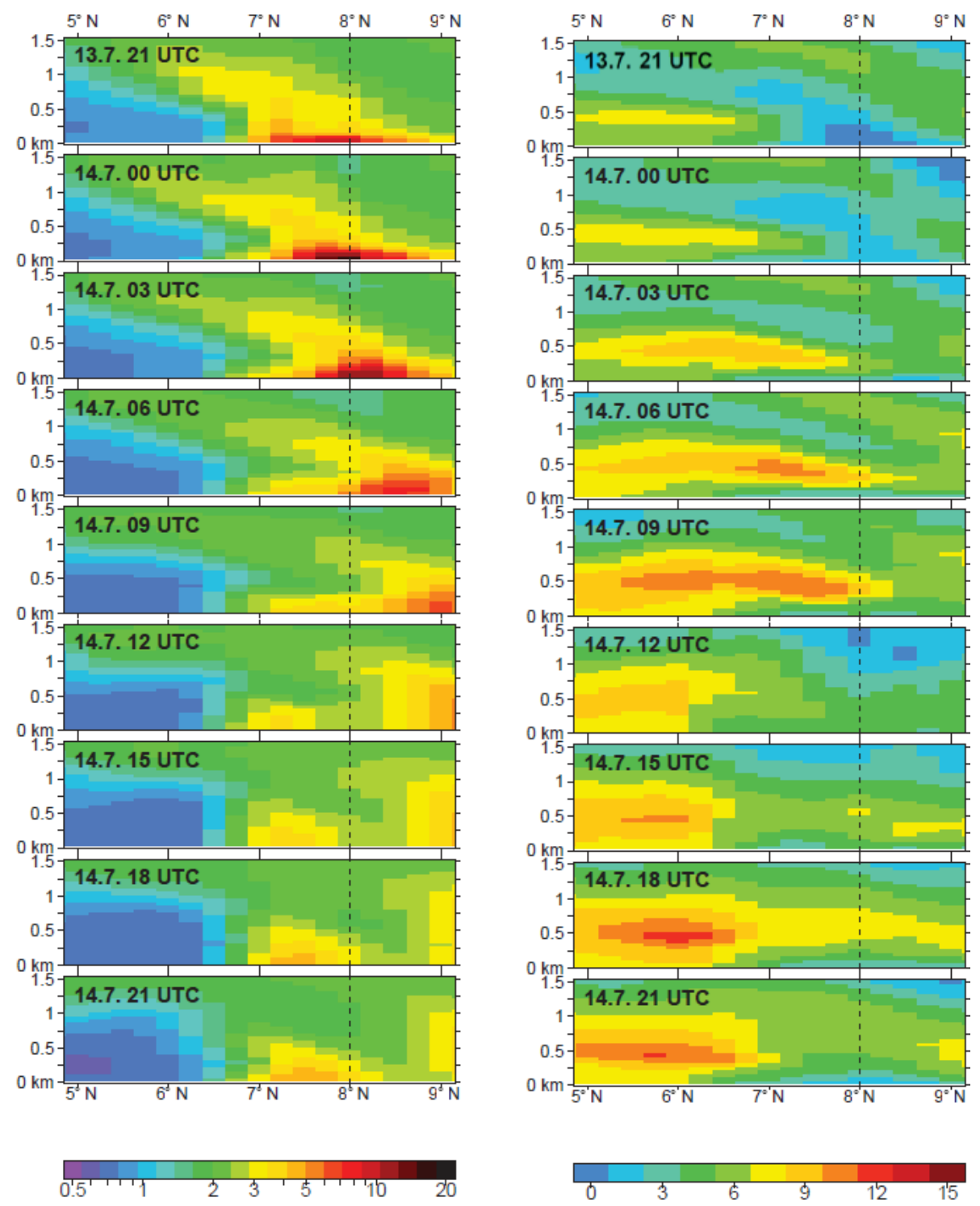

Figure 11. Vertical transect (km a.g.1.) from COSMO-ART of the total BC ( $\mu \mathrm{g} \mathrm{m}^{-3}$; left) and wind speed ( $\mathrm{m} \mathrm{s}^{-1}$; right) along the longitude of Savè between 21:00 UTC on 13 July 2016 and 21:00 UTC on 14 July 2016. The dashed line indicates the location of Savè.

tribution. Therefore, ground observations with a wind profiler, ceilometer, and gas concentrations were used from the Savè supersite, $4 \mathrm{~km}$ away from the research flights. $\mathrm{NO}_{x}$ and $\mathrm{CO}$ did not show any clear evidence of local emissions at the ground. However, maximum BC of $2.81 \pm 0.30 \mu \mathrm{g} \mathrm{m}^{-3}$ was observed in the residual layer between the heights of 400 and $600 \mathrm{~m}$ a.g.l. in relation to a nocturnal low-level jet with wind speeds higher than $12 \mathrm{~m} \mathrm{~s}^{-1}$. The lifted $\mathrm{BC}$ layer was vertically mixed during clear-sky conditions during the day, and the mass concentration increased continuously in the lowermost $1100 \mathrm{~m}$ a.g.l. On the next day, low-level clouds formed in the early morning that might have led to wash-out in the lowermost $400 \mathrm{~m}$ a.g.l. BC decreased from $3.87 \pm 0.79$ to $2.51 \pm 0.13 \mu \mathrm{g} \mathrm{m}^{-3}$ in the same altitude. The UAS obser- vations were supported and spatially extended by a comparison with the model output of COSMO-ART during the event. In all cases, the contribution of fresh $\mathrm{BC}$ to the total $\mathrm{BC}$ was negligible in COSMO-ART, indicating that local sources were not the major contributor of $\mathrm{BC}$ over Savè. The analysis of the longitudinal vertical transects of the modelled wind speed and the BC mass concentrations revealed that transport processes with maritime inflow from the south could be the most relevant contributors of the observed BC.

This hypothesis can be supported by the tracer experiments of Deroubaix et al. (2019), who showed that Savè is partly influenced by city plumes near the coast, namely Lomé, Accra, and Cotonou, due to maritime inflow from the south. The modelled period was 1-7 July, but the con- 
ditions of the vortex phase on 14 July 2016, which are unusual during the monsoon season, included the transport of aged biomass burning aerosol and decreased humidity, as described in Knippertz et al. (2017) and Flamant et al. (2018), so that long-range transport from city plumes might be the source of the observed BC in Savè.

The strength of the study shown here is the high capability to further understand transport processes of $\mathrm{BC}$ on the small scale by using UASs that are linked to the regional scale during the WAM season. However, the relationship between BC and the ABL needs more profound investigations. In addition, the impact of possibly aged and transported $\mathrm{BC}$ within the ABL should be taken into account in future investigations that could equally contribute to a reduction of air quality and even further interact with low-level clouds.

Data availability. The data used in this study (https://doi.org/10.6096/dacciwa.1618, Derrien et al., 2016; https://doi.org/10.6096/DACCIWA.1686, Handwerker et al., 2016; https://doi.org/10.6096/dacciwa.1659, Wieser et al., 2016; https://doi.org/10.6096/baobab-dacciwa.1701, Bärfuss et al., 2017) are available on the SEDOO database (http://baobab.sedoo.fr/DACCIWA/, last access: 3 July 2020).

Author contributions. $\mathrm{KD}$ and $\mathrm{BV}$ provided the COSMO-ART model contributions. $\mathrm{KaB}$ delivered the ceilometer profiles. $\mathrm{CD}$ studied the wind profiler data. FeP and CJ were responsible for the gas concentration observations. $\mathrm{KoB}, \mathrm{FaP}$, and $\mathrm{AL}$ handled the preparation and operation of the UAS, as well as the post-processing of the UAS data. FE contributed to the statistical analysis of the UAS measurements. BiA, NK, and FL coordinated the project and provided access to ground observation data. $\mathrm{BaA}$ wrote the publication under critical review and with input from all co-authors.

Competing interests. The authors declare that they have no conflict of interest.

Special issue statement. This article is part of the special issue "Results of the project "Dynamics-aerosol-chemistry-cloud interactions in West Africa" (DACCIWA) (ACP/AMT inter-journal SI)". It is not associated with a conference.

Acknowledgements. The DACCIWA project has received funding from the European Union Seventh Framework Programme (FP7/2007-2013) under grant agreement no. 603502. Barbara Altstädter was financially supported by the German Research Foundation (DFG) under the project number LA 2907/5-2. The authors from TU Braunschweig wish to thank UPS and KIT for being part of the DACCIWA project. We gratefully acknowledge Lutz Bretschneider, Endres Kathe, and Birgit Zachrau for their support in the preparation of the UAS ALADINA and during the experiment on site. We thank both referees for their critical input and valuable suggestions for improving the paper.

Financial support. We acknowledge support by the German Research Foundation and the Open Access Publication Funds of the Technische Universität Braunschweig.

This open-access publication was funded

by Technische Universität Braunschweig.

Review statement. This paper was edited by Dominick Spracklen and reviewed by two anonymous referees.

\section{References}

Adler, B., Babić, K., Kalthoff, N., Lohou, F., Lothon, M., Dione, C., Pedruzo-Bagazgoitia, X., and Andersen, H.: Nocturnal low-level clouds in the atmospheric boundary layer over southern West Africa: an observation-based analysis of conditions and processes, Atmos. Chem. Phys., 19, 663-681, https://doi.org/10.5194/acp-19-663-2019, 2019.

Adon, A. J., Liousse, C., Doumbia, E. T., Baeza-Squiban, A., Cachier, H., Léon, J.-F., Yoboué, V., Akpo, A. B., GalyLacaux, C., Guinot, B., Zouiten, C., Xu, H., Gardrat, E., and Keita, S.: Physico-chemical characterization of urban aerosols from specific combustion sources in West Africa at Abidjan in Côte d'Ivoire and Cotonou in Benin in the frame of the DACCIWA program, Atmos. Chem. Phys., 20, 5327-5354, https://doi.org/10.5194/acp-20-5327-2020, 2020.

Altstädter, B., Platis, A., Wehner, B., Scholtz, A., Wildmann, N., Hermann, M., Käthner, R., Baars, H., Bange, J., and Lampert, A.: ALADINA - an unmanned research aircraft for observing vertical and horizontal distributions of ultrafine particles within the atmospheric boundary layer, Atmos. Meas. Tech., 8, 16271639, https://doi.org/10.5194/amt-8-1627-2015, 2015.

Altstädter, B., Platis, A., Jähn, M., Baars, H., Lückerath, J., Held, A., Lampert, A., Bange, J., Hermann, M., and Wehner, B.: Airborne observations of newly formed boundary layer aerosol particles under cloudy conditions, Atmos. Chem. Phys., 18, 82498264, https://doi.org/10.5194/acp-18-8249-2018, 2018.

Babić, K., Kalthoff, N., Adler, B., Quinting, J. F., Lohou, F., Dione, C., and Lothon, M.: What controls the formation of nocturnal low-level stratus clouds over southern West Africa during the monsoon season?, Atmos. Chem. Phys., 19, 13489-13506, https://doi.org/10.5194/acp-19-13489-2019, 2019a.

Babić, K., Adler, B., Kalthoff, N., Andersen, H., Dione, C., Lohou, F., Lothon, M., and Pedruzo-Bagazgoitia, X.: The observed diurnal cycle of low-level stratus clouds over southern West Africa: a case study, Atmos. Chem. Phys., 19, 1281-1299, https://doi.org/10.5194/acp-19-1281-2019, 2019b.

Baldauf, M., Seifert, A., Förstner, J., Majewski, D., Raschendorfer, M., and Reinhardt, T.: Operational convective-scale numerical weather prediction with the COSMO model: description and sensitivities, Mon. Weather Rev., 139, 3887-3905, https://doi.org/10.1175/MWR-D-10-05013.1, 2011. 
Bärfuss, K., Pätzold, F., Hecker, P., and Lampert, A.: DACCIWA Savè super site. Atmospheric boundary layer properties and BC measured with the unmanned research aircraft ALADINA of the TU Braunschweig, SEDOO OMP, https://doi.org/10.6096/baobab-dacciwa.1701, 2017.

Bärfuss, K., Pätzold, F., Altstädter, B., Kathe, E., Nowak, S., Bretschneider, L., Bestmann, U., and Lampert, A.: New Setup of the UAS ALADINA for Measuring Boundary Layer Properties, Atmospheric Particles and Solar Radiation, Atmosphere, 9, 1-21, https://doi.org/10.3390/atmos9010028, 2018.

Båserud, L., Reuder, J., Jonassen, M. O., Kral, S. T., Paskyabi, M. B., and Lothon, M.: Proof of concept for turbulence measurements with the RPAS SUMO during the BLLAST campaign, Atmos. Meas. Tech., 9, 4901-4913, https://doi.org/10.5194/amt-94901-2016, 2016.

Bond, T. C., Doherty, S. J., Fahey, D. W., Forster, P. M., Berntsen, T., DeAngelo, B. J., Flanner, M. G., Ghan, S., Karcher, B., Koch, D., Kinne, S., Kondo, Y., Quinn, P. K., Sarofim, M. C., Schultz, M. G., Schulz, M., Venkataraman, C., Zhang, H., Zhang, S., Bellouin, N., Guttikunda, S. K., Hopke, P. K., Jacobson, M. Z., Kaiser, J. W., Klimont, Z., Lohmann, U., Schwarz, J. P., Shindell, D., Storelvmo, T., Warren, S. G., and Zender, C. S.: Bounding the role of black carbon in the climate system: A scientific assessment, J. Geophys. Res.-Atmos., 118, 5380-5552, https://doi.org/10.1002/Jgrd.50171, 2013.

Brosy, C., Krampf, K., Zeeman, M., Wolf, B., Junkermann, W., Schäfer, K., Emeis, S., and Kunstmann, H.: Simultaneous multicopter-based air sampling and sensing of meteorological variables, Atmos. Meas. Tech., 10, 2773-2784, https://doi.org/10.5194/amt-10-2773-2017, 2017.

Brito, J., Freney, E., Dominutti, P., Borbon, A., Haslett, S. L., Batenburg, A. M., Colomb, A., Dupuy, R., Denjean, C., Burnet, F., Bourriane, T., Deroubaix, A., Sellegri, K., Borrmann, S., Coe, H., Flamant, C., Knippertz, P., and Schwarzenboeck, A.: Assessing the role of anthropogenic and biogenic sources on $\mathrm{PM}_{1}$ over southern West Africa using aircraft measurements, Atmos. Chem. Phys., 18, 757-772, https://doi.org/10.5194/acp-18-7572018, 2018.

Chiliński, M. T., Markowicz, K. M., and Kubicki, M.: UAS as a Support for Atmospheric Aerosols Research: Case Study, Pure Appl. Geophys., 175, 3325-3342, https://doi.org/10.1007/s00024-018-1767-3, 2018.

Collaud Coen, M., Weingartner, E., Apituley, A., Ceburnis, D., Fierz-Schmidhauser, R., Flentje, H., Henzing, J. S., Jennings, S. G., Moerman, M., Petzold, A., Schmid, O., and Baltensperger, U.: Minimizing light absorption measurement artifacts of the Aethalometer: evaluation of five correction algorithms, Atmos. Meas. Tech., 3, 457-474, https://doi.org/10.5194/amt-3-4572010, 2010.

Corrigan, C. E., Roberts, G. C., Ramana, M. V., Kim, D., and Ramanathan, V.: Capturing vertical profiles of aerosols and black carbon over the Indian Ocean using autonomous unmanned aerial vehicles, Atmos. Chem. Phys., 8, 737-747, https://doi.org/10.5194/acp-8-737-2008, 2008.

Cuxart, J., Wrenger, B., Martínez-Villagrasa, D., Reuder, J., Jonassen, M. O., Jiménez, M. A., Lothon, M., Lohou, F., Hartogensis, O., Dünnermann, J., Conangla, L., and Garai, A.: Estimation of the advection effects induced by surface heterogeneities in the surface energy budget, Atmos. Chem. Phys., 16, 9489-9504, https://doi.org/10.5194/acp-16-9489-2016, 2016.

Deetz, K., Vogel, H., Knippertz, P., Adler, B., Taylor, J., Coe, H., Bower, K., Haslett, S., Flynn, M., Dorsey, J., Crawford, I., Kottmeier, C., and Vogel, B.: Numerical simulations of aerosol radiative effects and their impact on clouds and atmospheric dynamics over southern West Africa, Atmos. Chem. Phys., 18, 9767-9788, https://doi.org/10.5194/acp-18-9767-2018, 2018.

Deroubaix, A., Menut, L., Flamant, C., Brito, J., Denjean, C., Dreiling, V., Fink, A., Jambert, C., Kalthoff, N., Knippertz, P., Ladkin, R., Mailler, S., Maranan, M., Pacifico, F., Piguet, B., Siour, G., and Turquety, S.: Diurnal cycle of coastal anthropogenic pollutant transport over southern West Africa during the DACCIWA campaign, Atmos. Chem. Phys., 19, 473-497, https://doi.org/10.5194/acp-19-473-2019, 2019.

Derrien, S., Bezombes, Y., Bret, G., Gabella, O., Jarnot, C., Medina, P., Piques, E., Delon, C., Dione, C., Cambistron, B., Durand, P., Jambert, C., Lohou, F., Lothon, M., Pacifico, F., and Meyerfeld, Y.: DACCIWA field campaign, Savè super-site, UPS instrumentation, SEDOO OMP, https://doi.org/10.6096/dacciwa.1618, 2016.

Dione, C., Lohou, F., Lothon, M., Adler, B., Babić, K., Kalthoff, N., Pedruzo-Bagazgoitia, X., Bezombes, Y., and Gabella, O.: Lowlevel stratiform clouds and dynamical features observed within the southern West African monsoon, Atmos. Chem. Phys., 19, 8979-8997, https://doi.org/10.5194/acp-19-8979-2019, 2019.

Ferrero, L., Castelli, M., Ferrini, B. S., Moscatelli, M., Perrone, M. G., Sangiorgi, G., D’Angelo, L., Rovelli, G., Moroni, B., Scardazza, F., Močnik, G., Bolzacchini, E., Petitta, M., and Cappelletti, D.: Impact of black carbon aerosol over Italian basin valleys: high-resolution measurements along vertical profiles, radiative forcing and heating rate, Atmos. Chem. Phys., 14, 96419664, https://doi.org/10.5194/acp-14-9641-2014, 2014.

Flamant, C., Knippertz, P., Fink, A. H., Akpo, A., Brooks, B., Chiu, C. J., Coe, H., Danuor, S., Evans, M., Jegede, O., Kalthoff, N., Konaré, A., Liousse, C., Lohou, F., Mari, C., Schlager, H., Schwarzenboeck, A., Adler, B., Amekudzi, L., Aryee, J., Ayoola, M., Batenburg, A. M., Bessardon, G., Borrmann, S., Brito, J., Bower, K., Burnet, F., Catoire, V., Colomb, A., Denjean, C., Fosu-Amankwah, K. , Hill, P. G., Lee, J., Lothon, M., Maranan, M., Marsham, J., Meynadier, R., Ngamini, J., Rosenberg, P., Sauer, D., Smith, V., Stratmann, G., Taylor, J. W., Voigt, C., and V. Yoboué: The Dynamics-Aerosol-ChemistryCloud Interactions in West Africa Field Campaign: Overview and Research Highlights, B. Am. Meteorol. Soc., 99, 83-104, https://doi.org/10.1175/BAMS-D-16-0256.1, 2018.

Handwerker, J., Scheer, S., and Gamer, T.: DACCIWA field campaign, Savè super-site, Cloud and precipitation, SEDOO OMP https://doi.org/10.6096/DACCIWA.1686, 2016.

Hansen, A. D. A., Rosen, H., and Novakov, T.: The aethalometer-an instrument for the real-time measurement of optical absorption by aerosol particles, Sci. Total Environ., 36, 191-196, 1984.

Huang, J., Adams, A., Wang, C., and Zhang, C.: Black Carbon and West African Monsoon precipitation: observations and simulations, Ann. Geophys., 27, 4171-4181, https://doi.org/10.5194/angeo-27-4171-2009, 2009.

Jiménez, M. A., Simó, G, Wrenger, B., Telisman-Prtenjak, M., Guijarro, J. A., and Cuxart, J.: Morning transition case between the 
land and the sea breeze regimes, Atmos. Res., 172-173, 95-108, https://doi.org/10.1016/j.atmosres.2015.12.019, 2016.

Kalthoff, N., Lohou, F., Brooks, B., Jegede, G., Adler, B., Babić, K., Dione, C., Ajao, A., Amekudzi, L. K., Aryee, J. N. A., Ayoola, M., Bessardon, G., Danuor, S. K., Handwerker, J., Kohler, M., Lothon, M., Pedruzo-Bagazgoitia, X., Smith, V., Sunmonu, L., Wieser, A., Fink, A. H., and Knippertz, P.: An overview of the diurnal cycle of the atmospheric boundary layer during the West African monsoon season: results from the 2016 observational campaign, Atmos. Chem. Phys., 18, 2913-2928, https://doi.org/10.5194/acp-18-2913-2018, 2018.

Knippertz, P., Evans, M. J., Field, P. R., Fink, A. H., Liousse, C., and Marsham, J. H.: The possible role of local air pollution in climate change in West Africa, Nat. Clim. Change, 5, 815-822, https://doi.org/10.1038/NCLIMATE2727, 2015a.

Knippertz, P., Coe, H., Chiu, J. C., Evans, M. J., Fink, A. H., Kalthoff, N., Liousse, C., Mari, C., Allan, R. P., Brooks, B., Danour, S., Flamant, C., Jegede, O. O., Lohou, F., and Marsham, J. H.: The DACCIWA project: Dynamics-aerosolchemistry-cloud interactions in West Africa, B. Am. Meteorol. Soc., 96, 1451-1460, https://doi.org/10.1175/BAMS-D-1400108.1, 2015b.

Knippertz, P., Fink, A. H., Deroubaix, A., Morris, E., Tocquer, F., Evans, M. J., Flamant, C., Gaetani, M., Lavaysse, C., Mari, C., Marsham, J. H., Meynadier, R., Affo-Dogo, A., Bahaga, T., Brosse, F., Deetz, K., Guebsi, R., Latifou, I., Maranan, M., Rosenberg, P. D., and Schlueter, A.: A meteorological and chemical overview of the DACCIWA field campaign in West Africa in June-July 2016, Atmos. Chem. Phys., 17, 10893-10918, https://doi.org/10.5194/acp-17-10893-2017, 2017.

Lee, J.: Performance Test of MicroAeth ${ }^{\circledR}$ AE51 at Concentrations Lower than $2 \mu \mathrm{g} \mathrm{m}^{-3}$ in Indoor Laboratory, Appl. Sci., 9, 1-14, https://doi.org/10.3390/app9132766, 2019.

Li, Z., Liu, J., Mauzerall, D. L., Li, X., Fan, S., Horowitz, L. W., He, C., Yi, K., and Tao, S.: A potential large and persistent black carbon forcing over Northern Pacific inferred from satellite observations, Sci. Rep., 7, 43429, 1-8, https://doi.org/10.1038/srep43429, 2017.

Liousse, C., Assamoi, E., Criqui, E. P., Granier, C., and Rosset, R.: Explosive growth in African combustion emissions from 2005 to 2030, Environ. Res. Lett., 9, 035003, 1-10, https://doi.org/10.1088/1748-9326/9/3/035003, 2014.

Liu, B., Ma, Y., Gong, W., Zhang, M., and Shi, Y.: The relationship between black carbon and atmospheric boundary layer height, Atmos. Pollut. Res., 10, 65-72, https://doi.org/10.1016/j.apr.2018.06.007, 2018.

Mari, C. H., Cailley, G., Corre, L., Saunois, M., Attié, J. L., Thouret, V., and Stohl, A.: Tracing biomass burning plumes from the Southern Hemisphere during the AMMA 2006 wet season experiment, Atmos. Chem. Phys., 8, 3951-3961, https://doi.org/10.5194/acp-8-3951-2008, 2008.

Marino, M., Fisher, A., Clothier, R., Watkins, S., Prudden, S., and Leung, C. S.: An Evaluation of Multi-Rotor Unmanned Aircraft as Flying Wind Sensors, Int. J. Micro Air Veh., 7, 285-299, https://doi.org/10.1260/1756-8293.7.3.285, 2015.

Mayer, S., Sandvik, A., Jonassen, M., and Reuder, J.: Atmospheric profiling with the UAS SUMO: a new perspective for the evaluation of fine-scale atmospheric models, Meteorol. Atmos. Phys., 116, 15-26, https://doi.org/10.1007/s00703-010-0063-2, 2010.
Pacifico, F., Delon, C., Jambert, C., Durand, P., Morris, E., Evans, M. J., Lohou, F., Derrien, S., Donnou, V. H. E., Houeto, A. V., Reinares Martínez, I., and Brilouet, P.-E.: Measurements of nitric oxide and ammonia soil fluxes from a wet savanna ecosystem site in West Africa during the DACCIWA field campaign, Atmos. Chem. Phys., 19, 2299-2325, https://doi.org/10.5194/acp19-2299-2019, 2019.

Platis, A., Altstädter, B., Wehner, B., Wildmann, N., Lampert. A., Hermann, M., Birmili, W., and Bange, J.: An observational case study on the influence of atmospheric boundary layer dynamics on the new particle formation, Bound.-Lay. Meteorol., 158, 6792, https://doi.org/10.1007/s10546-015-0084-y, 2016.

Petäjä, T., Järvi, L., Kerminen, V. M., Ding, A. J., Sun, J. N., Nie, W., Kujansuu, J., Virkkula, A., Yang, X., Fu, C. B., Zilitinkevich, S., and Kulmala, M.: Enhanced air pollution via aerosol-boundary layer feedback in China, Sci. Rep., 6, 18998, https://doi.org/10.1038/srep18998, 2016.

Petzold, A., Ogren, J. A., Fiebig, M., Laj, P., Li, S.-M., Baltensperger, U., Holzer-Popp, T., Kinne, S., Pappalardo, G., Sugimoto, N., Wehrli, C., Wiedensohler, A., and Zhang, X.-Y.: Recommendations for reporting "black carbon" measurements, Atmos. Chem. Phys., 13, 8365-8379, https://doi.org/10.5194/acp13-8365-2013, 2013.

Pikridas, M., Bezantakos, S., Močnik, G., Keleshis, C., Brechtel, F., Stavroulas, I., Demetriades, G., Antoniou, P., Vouterakos, P., Argyrides, M., Liakakou, E., Drinovec, L., Marinou, E., Amiridis, V., Vrekoussis, M., Mihalopoulos, N., and Sciare, J.: On-flight intercomparison of three miniature aerosol absorption sensors using unmanned aerial systems (UASs), Atmos. Meas. Tech., 12, 6425-6447, https://doi.org/10.5194/amt-12-6425-2019, 2019.

Ran, L., Deng, Z., Xu, X., Yan, P., Lin, W., Wang, Y., Tian, P., Wang, P., Pan, W., and Lu, D.: Vertical profiles of black carbon measured by a micro-aethalometer in summer in the North China Plain, Atmos. Chem. Phys., 16, 10441-10454, https://doi.org/10.5194/acp-16-10441-2016, 2016.

Renard, J.-B., Dulac, F., Berthet, G., Lurton, T., Vignelles, D., Jégou, F., Tonnelier, T., Jeannot, M., Couté, B., Akiki, R., Verdier, N., Mallet, M., Gensdarmes, F., Charpentier, P., Mesmin, S., Duverger, V., Dupont, J.-C., Elias, T., Crenn, V., Sciare, J., Zieger, P., Salter, M., Roberts, T., Giacomoni, J., Gobbi, M., Hamonou, E., Olafsson, H., Dagsson-Waldhauserova, P., Camy-Peyret, C., Mazel, C., Décamps, T., Piringer, M., Surcin, J., and Daugeron, D.: LOAC: a small aerosol optical counter/sizer for ground-based and balloon measurements of the size distribution and nature of atmospheric particles - Part 2: First results from balloon and unmanned aerial vehicle flights, Atmos. Meas. Tech., 9, 36733686, https://doi.org/10.5194/amt-9-3673-2016, 2016.

Riemer, N., Vogel, H., and Vogel, B.: Soot aging time scales in polluted regions during day and night, Atmos. Chem. Phys., 4, 1885-1893, https://doi.org/10.5194/acp-4-1885-2004, 2004.

Saturno, J., Pöhlker, C., Massabò, D., Brito, J., Carbone, S., Cheng, Y., Chi, X., Ditas, F., Hrabě de Angelis, I., Morán-Zuloaga, D., Pöhlker, M. L., Rizzo, L. V., Walter, D., Wang, Q., Artaxo, P., Prati, P., and Andreae, M. O.: Comparison of different Aethalometer correction schemes and a reference multiwavelength absorption technique for ambient aerosol data, Atmos. Meas. Tech., 10, 2837-2850, https://doi.org/10.5194/amt10-2837-2017, 2017. 
Stockwell, W. R., Middleton, P., Chang, J. S., and Tang, X.: The second generation regional acid deposition model chemical mechanism for regional air quality modeling, J. Geophys. Res.-Atmos., 95, 16343-16367, https://doi.org/10.1029/JD095iD10p16343, 1990.

Virkkula, A., Mäkelä, T., Hillamo, R., Yli-Tuomi, T., Hirsikko, A., Hämeri, K., and Koponen, I. K.: A simple procedure for correcting loading effects of aethalometer data, J. Air Waste Manage., 57, 1214-1222, https://doi.org/10.3155/1047-3289.57.10.1214, 2007.

Vogel, B., Vogel, H., Bäumer, D., Bangert, M., Lundgren, K., Rinke, R., and Stanelle, T.: The comprehensive model system COSMOART - Radiative impact of aerosol on the state of the atmosphere on the regional scale, Atmos. Chem. Phys., 9, 8661-8680, https://doi.org/10.5194/acp-9-8661-2009, 2009.

Weingartner, E., Saathoff, H., Schnaiter, M., Streit, N., Bitnar, B., and Baltensperger, U.: Absorption of light by soot particles: determination of the absorption coefficient by means of aethalometers, J. Aerosol Sci., 34, 1445-1463, https://doi.org/10.1016/S0021-8502(03)00359-8, 2003.

Wilcox, E. M., Thomas, R. M., Praveen, P. S., Pistone, K., Bender, F. A., and Ramanathan, V.: Black carbon solar absorption suppresses turbulence in the atmospheric boundary layer, P. Natl. Acad. Sci. USA, 113, 11794-11799, https://doi.org/10.1073/pnas.1525746113, 2016.
Wieser, A., Adler, B., and Deny, B.: DACCIWA field campaign, Savè super-site, Thermodynamic data sets, SEDOO OMP, https://doi.org/10.6096/dacciwa.1659, 2016.

Wildmann, N., Mauz, M., and Bange, J.: Two fast temperature sensors for probing of the atmospheric boundary layer using small remotely piloted aircraft (RPA), Atmos. Meas. Tech., 6, 21012113, https://doi.org/10.5194/amt-6-2101-2013, 2013.

Wildmann, N., Ravi, S., and Bange, J.: Towards higher accuracy and better frequency response with standard multi-hole probes in turbulence measurement with remotely piloted aircraft (RPA), Atmos. Meas. Tech., 7, 1027-1041, https://doi.org/10.5194/amt7-1027-2014, 2014.

Zhang, R. Y., Khalizov, A. F., Pagels, J., Zhang, D., Xue, H. X., and McMurry, P. H.: Variability in morphology, hygroscopicity, and optical properties of soot aerosols during atmospheric processing, P. Natl. Acad. Sci. USA, 105, 10291-10296, https://doi.org/10.1073/pnas.0804860105, 2008. 